\title{
LEVEL II SCOUR ANALYSIS FOR BRIDGE 43 (SPRICYBRIG0043) on BRIDGE STREET, crossing the BLACK RIVER, SPRINGFIELD, VERMONT
}

U.S. Geological Survey Open-File Report 97-227

Prepared in cooperation with

VERMONT AGENCY OF TRANSPORTATION and

FEDERAL HIGHWAY ADMINISTRATION 


\section{LEVEL II SCOUR ANALYSIS FOR BRIDGE 43 (SPRICYBRIG0043) on BRIDGE STREET, crossing the BLACK RIVER, SPRINGFIELD, VERMONT \\ By MICHAEL A. IVANOFF and LAURA MEDALIE}

U.S. Geological Survey Open-File Report 97-227

Prepared in cooperation with

VERMONT AGENCY OF TRANSPORTATION and

FEDERAL HIGHWAY ADMINISTRATION 


\title{
U.S. DEPARTMENT OF THE INTERIOR BRUCE BABBITT, Secretary
}

\author{
U.S. GEOLOGICAL SURVEY \\ Gordon P. Eaton, Director
}

For additional information write to:

District Chief

U.S. Geological Survey 361 Commerce Way

Pembroke, NH 03275-3718
Copies of this report may be purchased from:

U.S. Geological Survey

Branch of Information Services

Open-File Reports Unit

Box 25286

Denver, CO 80225-0286 


\section{CONTENTS}

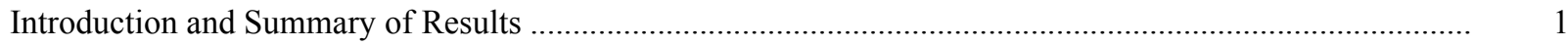

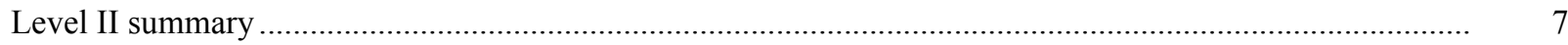

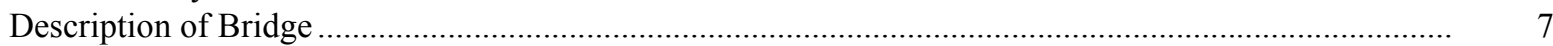

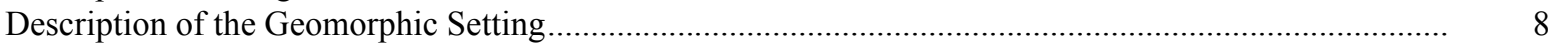

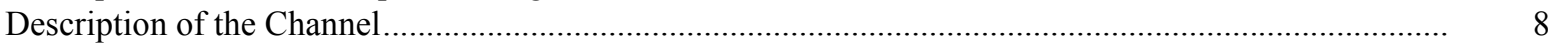

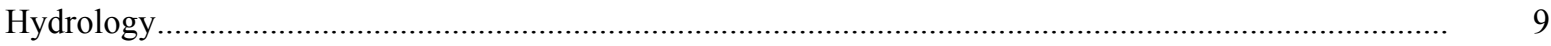

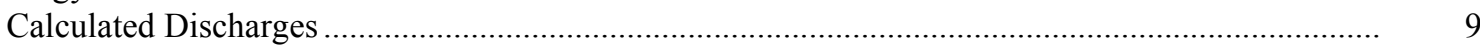

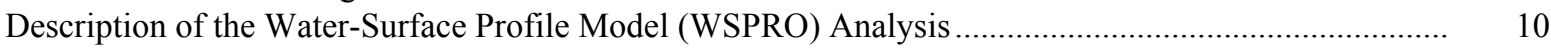

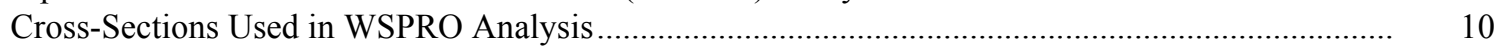

Data and Assumptions Used in WSPRO Model ...................................................................... 11

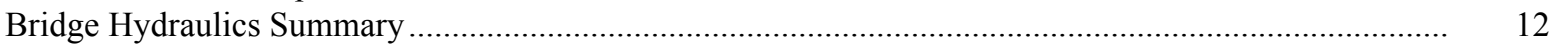

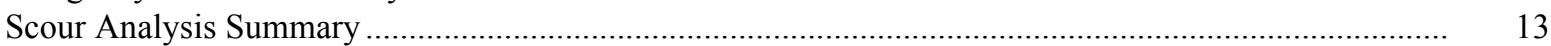

Special Conditions or Assumptions Made in Scour Analysis ...................................................... 13

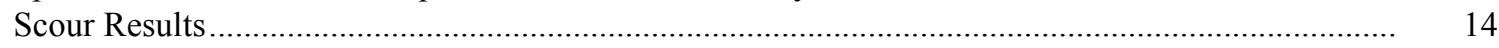

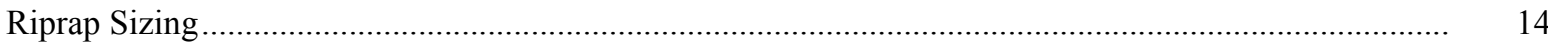

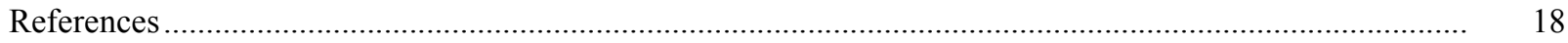

Appendixes:

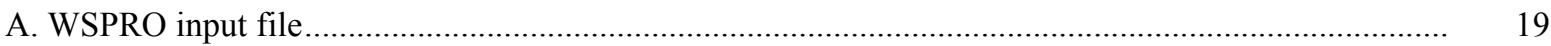

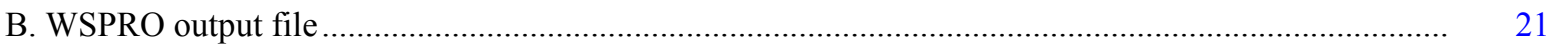

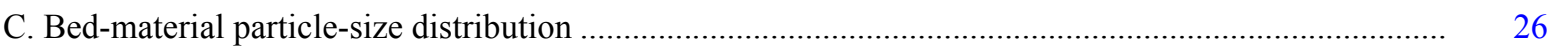

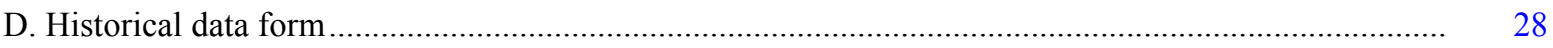

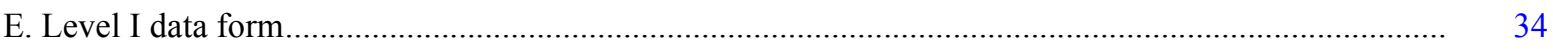

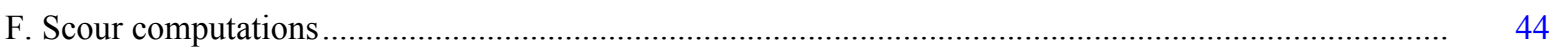

\section{FIGURES}

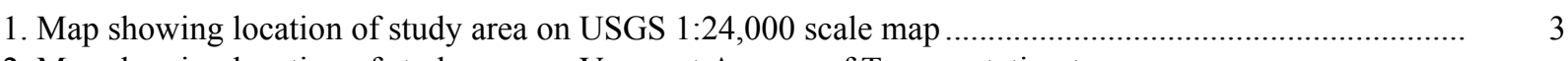

2. Map showing location of study area on Vermont Agency of Transportation town
highway map

3. Structure SPRICYBRIG0043 viewed from upstream (September 19, 1996) .......................................... 5

4. Downstream channel viewed from structure SPRICYBRIG0043 (September 19, 1996), ........................ 5

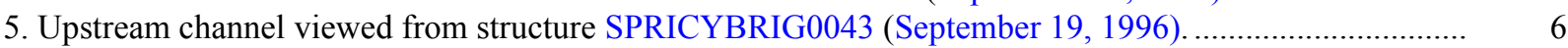

6. Structure SPRICYBRIG0043 viewed from downstream (September 19, 1996)................................... 6

7. Water-surface profiles for the 100- and 500-year discharges at structure

SPRICYBRIG0043 on Bridge Street, crossing the Black River,

Springfield, Vermont.

8. Scour elevations for the 100- and 500-year discharges at structure

SPRICYBRIG0043 on Bridge Street, crossing the Black River,

Springfield, Vermont.

\section{TABLES}

1. Remaining footing/pile depth at abutments for the 100-year discharge at structure

SPRICYBRIG0043 on Bridge Street, crossing the Black River,

Springfield, Vermont

2. Remaining footing/pile depth at abutments for the 500-year discharge at structure

SPRICYBRIG0043 on Bridge Street, crossing the Black River,

Springfield, Vermont

5
(5 


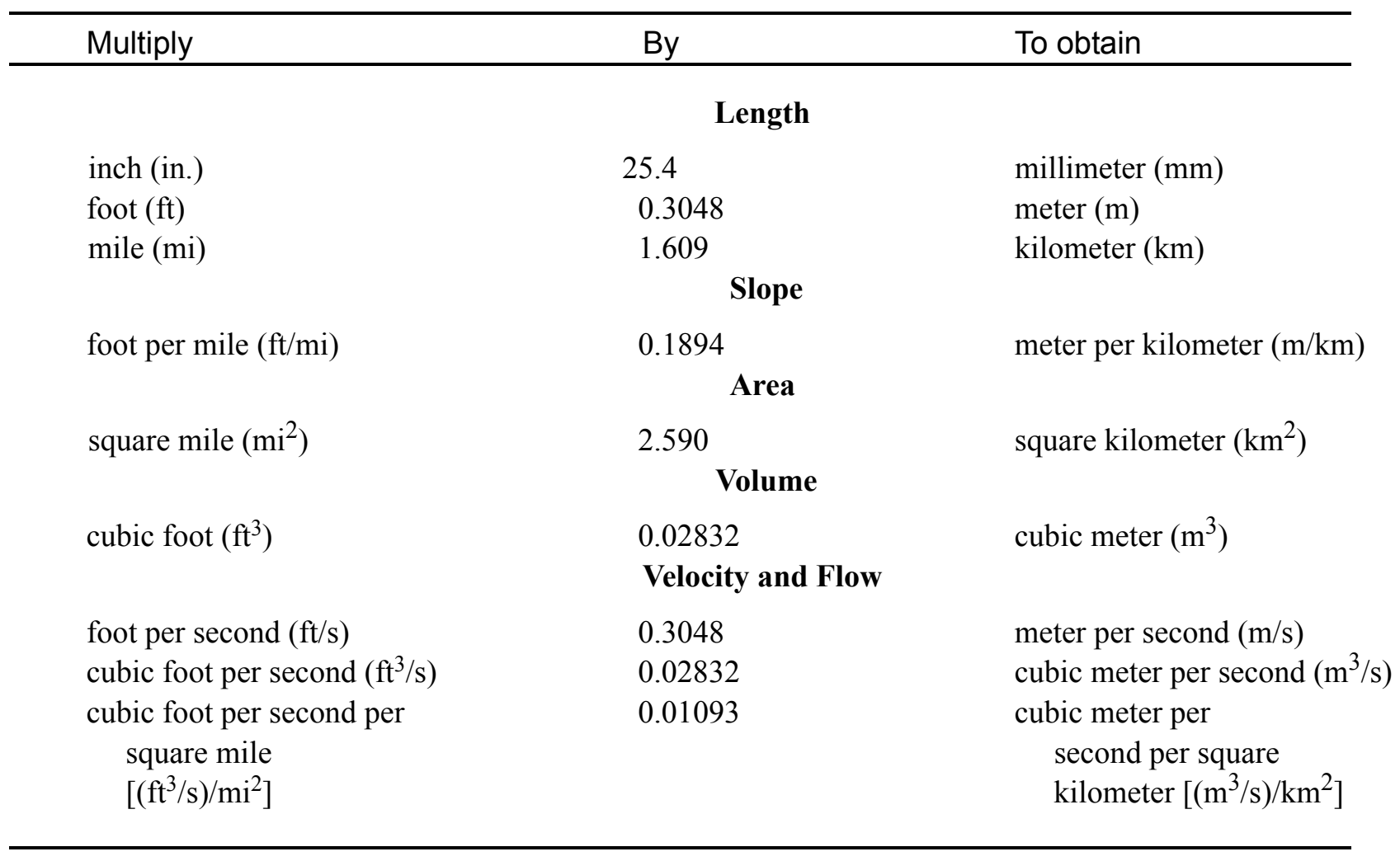

\section{OTHER ABBREVIATIONS}

$\begin{array}{lrlr}\mathrm{BF} & \text { bank full } & \text { LWW } & \text { left wingwall } \\ \mathrm{cfs} & \text { cubic feet per second } & \text { MC } & \text { main channel } \\ \mathrm{D}_{50} & \text { median diameter of bed material } & \text { RAB } & \text { right abutment } \\ \mathrm{DS} & \text { downstream } & \text { RABUT } & \text { face of right abutment } \\ \mathrm{elev} & \text { elevation } & \text { RB } & \text { right bank } \\ \mathrm{f} / \mathrm{p} & \text { flood plain } & \text { ROB } & \text { right overbank } \\ \mathrm{ft}^{2} & \text { square feet } & \text { RWW } & \text { right wingwall } \\ \mathrm{ft} / \mathrm{ft} & \text { feet per foot } & \text { TH } & \text { town highway } \\ \mathrm{JCT} & \text { junction } & \text { UB } & \text { under bridge } \\ \mathrm{LAB} & \text { left abutment } & \text { US } & \text { upstream } \\ \mathrm{LABUT} & \text { face of left abutment } & \text { USGS } & \text { United States Geological Survey } \\ \mathrm{LB} & \text { left bank } & \text { VTAOT Vermont Agency of Transportation } \\ \mathrm{LOB} & \text { left overbank } & \text { WSPRO } & \text { water-surface profile model }\end{array}$

In this report, the words "right" and "left" refer to directions that would be reported by an observer facing downstream. Sea level: In this report, "sea level" refers to the National Geodetic Vertical Datum of 1929-- a geodetic datum derived from a general adjustment of the first-order level nets of the United States and Canada, formerly called Sea Level Datum of 1929.

In the appendices, the above abbreviations may be combined. For example, USLB would represent upstream left bank. 


\title{
LEVEL II SCOUR ANALYSIS FOR BRIDGE 43 (SPRICYBRIG0043) ON BRIDGE STREET, CROSSING THE BLACK RIVER, SPRINGFIELD, VERMONT
}

\author{
By Michael A. Ivanoff and Laura Medalie
}

\section{INTRODUCTION AND SUMMARY OF RESULTS}

This report provides the results of a detailed Level II analysis of scour potential at structure SPRICYBRIG0043 on Bridge Street crossing the Black River, Springfield, Vermont (figures 1-8). A Level II study is a basic engineering analysis of the site, including a quantitative analysis of stream stability and scour (U.S. Department of Transportation, 1993). Results of a Level I scour investigation also are included in Appendix E of this report. A Level I investigation provides a qualitative geomorphic characterization of the study site. Information on the bridge, gleaned from Vermont Agency of Transportation (VTAOT) files, was compiled prior to conducting Level I and Level II analyses and is found in Appendix D.

The site is in the New England Upland section of the New England physiographic province in southeastern Vermont. The 191- $\mathrm{mi}^{2}$ drainage area is a predominantly rural and forested basin. In the vicinity of the study site, the surface cover consist of some grass, buildings, and pavement. The immediate banks are covered with trees, shrubs and brush.

In the study area, the Black River has an incised channel with a slope of approximately $0.001 \mathrm{ft} / \mathrm{ft}$, an average channel top width of $156 \mathrm{ft}$ and an average bank height of $14 \mathrm{ft}$. The channel bed material is predominantly cobbles with a median grain size $\left(\mathrm{D}_{50}\right)$ of $90.7 \mathrm{~mm}$ $(0.298 \mathrm{ft})$. The geomorphic assessment at the time of the Level I and Level II site visit on September 19, 1996, indicated that the reach was stable.

The Bridge Street crossing of the Black River is a 123 -foot-long, two-lane bridge consisting of one 119-foot steel-beam span (Vermont Agency of Transportation, written communication, March 30,1995). The bridge is supported by vertical, concrete abutments with wingwalls. The channel is skewed approximately 20 degrees to the opening while the opening-skew-to-roadway is 20 degrees. 
The scour protection measures at the site were type- 2 stone fill (less than 36 inches diameter) along the downstream left bank and the downstream left wingwall. There was also type-1 stone fill (less than 12 inches diameter) along right abutment and the downstream right wingwall. There is a nine foot tall concrete wall along the downstream right bank to 89 feet downstream of the bridge. Additional details describing conditions at the site are included in the Level II Summary and Appendices D and E.

Scour depths and recommended rock rip-rap sizes were computed using the general guidelines described in Hydraulic Engineering Circular 18 (Richardson and others, 1995). Total scour at a highway crossing is comprised of three components: 1) long-term streambed degradation; 2) contraction scour (due to accelerated flow caused by a reduction in flow area at a bridge) and; 3 ) local scour (caused by accelerated flow around piers and abutments). Total scour is the sum of the three components. Equations are available to compute depths for contraction and local scour and a summary of the results of these computations follows.

There was no computed contraction scour. Left abutment scour ranged from 9.9 to $11 \mathrm{ft}$. The worst-case left abutment scour occurred at the 100-year discharge. Right abutment scour ranged from 6.5 to $11.2 \mathrm{ft}$. The worst-case right abutment scour occurred at the 500year discharge. Additional information on scour depths and depths to armoring are included in the section titled "Scour Results". Scoured-streambed elevations, based on the calculated scour depths, are presented in tables 1 and 2. A cross-section of the scour computed at the bridge is presented in figure 8 . Scour depths were calculated assuming an infinite depth of erosive material and a homogeneous particle-size distribution.

It is generally accepted that the Froehlich equation (abutment scour) gives "excessively conservative estimates of scour depths" (Richardson and others, 1995, p. 47). Usually, computed scour depths are evaluated in combination with other information including (but not limited to) historical performance during flood events, the geomorphic stability assessment, existing scour protection measures, and the results of the hydraulic analyses. Therefore, scour depths adopted by VTAOT may differ from the computed values documented herein. 


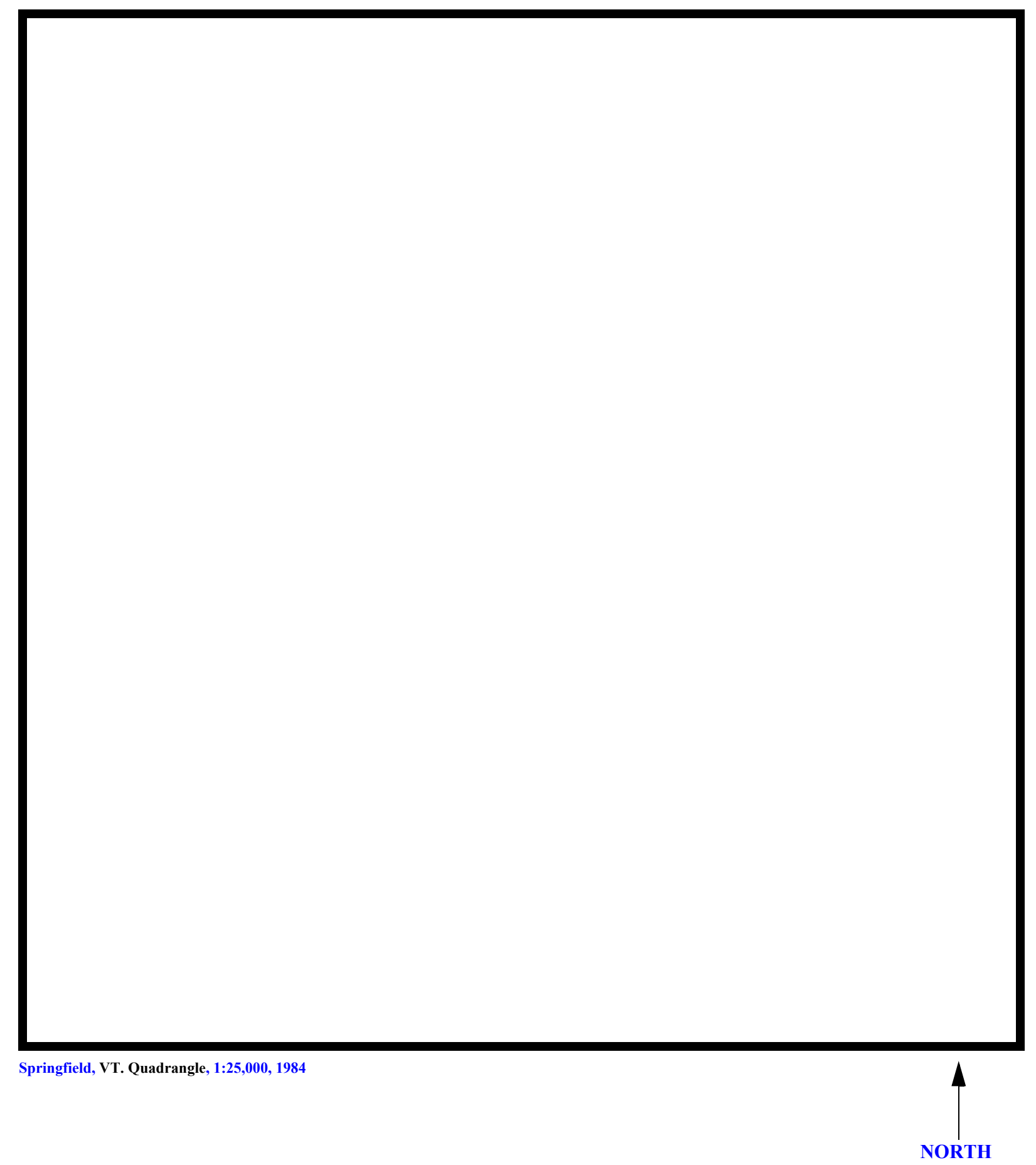

Figure 1. Location of study area on USGS 1:24,000 scale map. 
Figure 2. Location of study area on Vermont Agency of Transportation town highway map. 

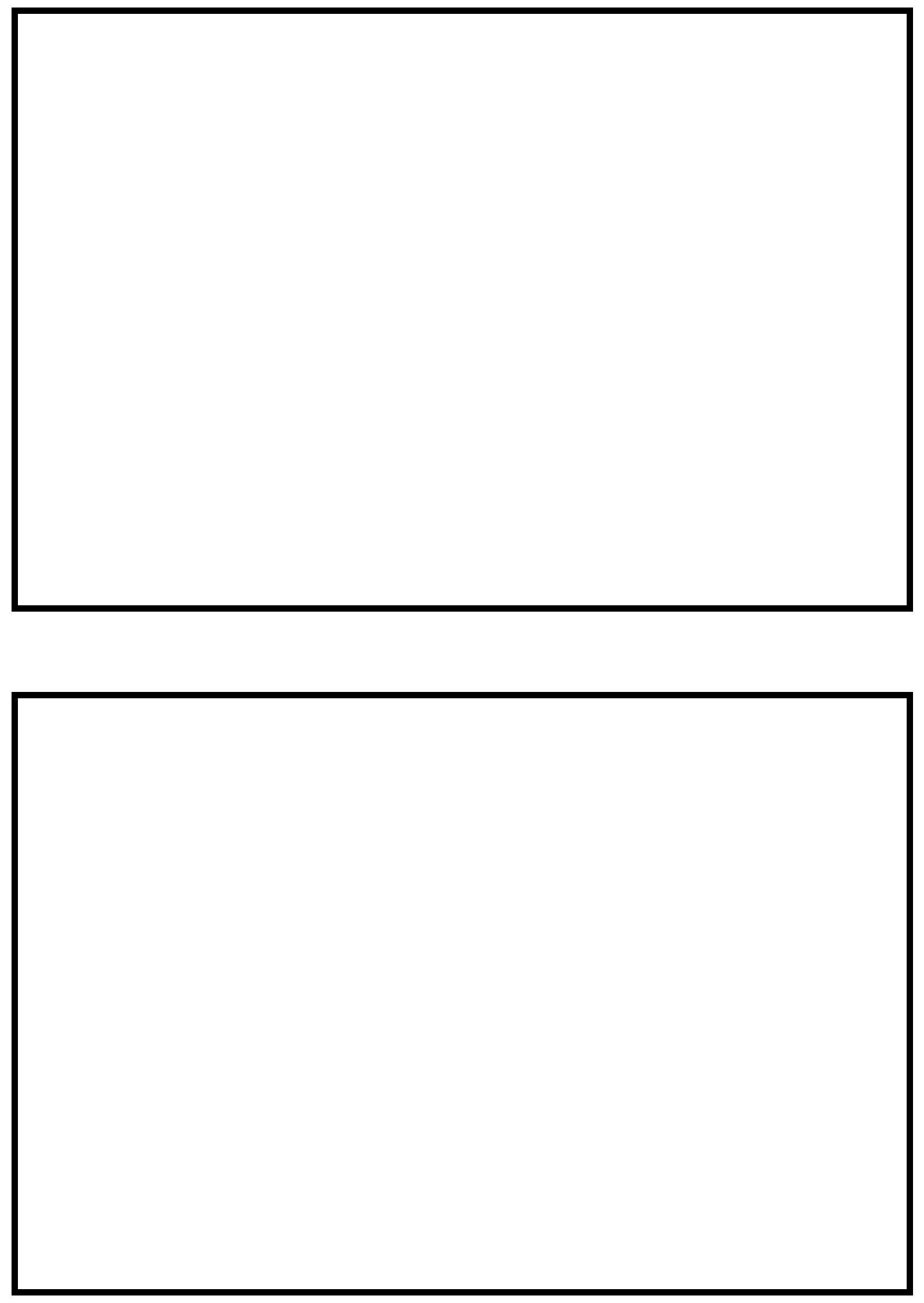


\section{LEVEL II SUMMARY}

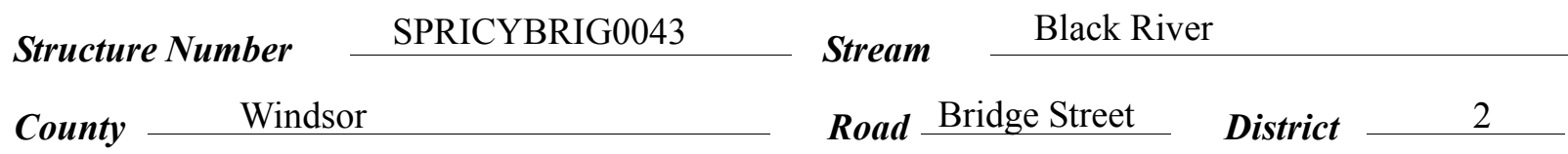

\section{Description of Bridge}

Bridge length $\stackrel{123}{\quad} \boldsymbol{f t}$ Bridge width $\quad$ ft Max span length $\frac{119}{f t}$ Alignment of bridge to road (on curve or straight) Vertical, concrete Abutment type

Stone fill on abutment?

$$
\text { Yes, right }
$$

Embankment type Straight

\section{None}

$09 / 19 / 96$

downstream left bank. Type-1, along the right abutment and the downstream right wingwall.

Abutments and wingwalls are concrete.

Yes

$\underline{20} \quad \underline{\text { No }}$

Is bridge skewed to flood flow according to 'survey?

Angle

$09 / 19 / 96$

Debris accumulation on bridge at time of Level I or Level II site visit:

\begin{tabular}{|c|c|c|c|}
\hline & $\begin{array}{c}\text { Date of insnortion } \\
\underline{0}\end{array}$ & $\begin{array}{l}\text { Percent of almmust } \\
\text { blocked inortzontatly }\end{array}$ & $\begin{array}{l}\text { Percent of } 09 / 19 / \text { iel } \\
\text { blocked verticatty }\end{array}$ \\
\hline & $\underline{96}$ & 0 & 0 \\
\hline & Low. & & \\
\hline
\end{tabular}

\section{Potential for debris}

None 09/19/96.

Dosrriho anv, fonturos noar ar at tho hridoo that mav, affort flow (includo ahsorvation dato) 


\section{Description of the Geomorphic Setting}

General topography The channel is located within a moderate relief valley, with a narrow flood plain and steep valley walls on both sides.

Geomorphic conditions at bridge site: downstream (DS), upstream (US)

Date of inspection $\quad 09 / 19 / 96$

DS left: $\quad$ Steep channel bank to a narrow flood plain.

DS right: $\quad$ Moderately sloped channel bank to a narrow flood plain.

US left: $\quad$ Steep channel bank to a narrow flood plain.

US right: $\quad$ Steep channel bank to a narrow flood plain.

\section{Description of the Channel}

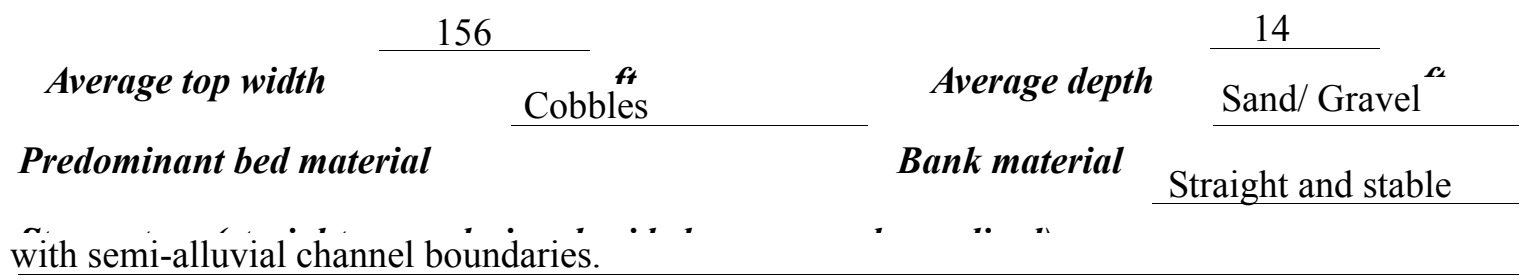

$09 / 19 / 96$

Vegetative co ${ }^{1}$ Brush on the bank with grass on the flood plain.

DS left: $\quad$ Trees and brush on bank with grass on the flood plain.

DS right: $\quad$ Brush on the bank with grass on the flood plain.

US left: $\quad$ Trees and brush on bank with grass on the flood plain.

US right: $\quad$ Yes

Do banks appear stable? -

y mus, ме

date of observatton.

None 09/19/96

Describe any obstructions in channel and date of observation. 


\section{Hydrology}

Drainage area $\frac{191}{m i^{2}}$

Percentage of drainage area in physiographic provinces: (approximate)

Physiographic province/section New England/ New England Upland
Percent of drainage area 100

Is drainage area considered rural or urban? Rural Describe any significant urbanization: There are factory buildings on the upstream and downstream right bank.

Yes, discontinued 1989

Black River at North

Is there a USGS gage on the stream of interest? Springfield, VT USGS gage description 01153000

USGS gage number

Gage drainage area $\mathbf{m i}^{2}$ No

Is there a lake/p -

\section{Calculated Discharges $\quad 9,910$ \\ Q100 $\quad \mathrm{ft}^{3} / \mathrm{s} \quad \mathrm{Q500} \quad \mathrm{ft} / \mathrm{s}$}

The 100- and 500-year discharges at this site are

based on a drainage area relationship [(191/194)exp 0.7] with the Black River upstream of

Seaver Brook. The Black River upstream of Seaver Brook has flood frequency estimates available in the Flood Insurance Study for Springfield, VT (Federal Emergency Management Agency, June 1979). The drainage area on the Black River upstream of Seaver Brook is 194 square miles. These values were within a range defined by several empirical flood frequency curves (Benson, 1962; Johnson and Tasker, 1974; FHWA, 1983; Potter, 1957a\&b; Talbot, 1887). 


\section{Description of the Water-Surface Profile Model (WSPRO) Analysis}

Datum for WSPRO analysis (USGS survey, sea level, VTAOT plans)

USGS survey

Datum tie between USGS survey and VTAOT plans

Subtract 161.8 feet from the

USGS survey to obtain VTAOT plans' datum.

Description of reference marks used to determine USGS datum. $\quad$ RM1 is a VTAOT tablet

on top of the downstream end of the right abutment (elev. $501.91 \mathrm{ft}$, arbitrary survey datum).

RM2 is a chiseled $X$ on top of the downstream end of the left abutment (elev. 499.71ft, arbitrary

survey datum).

\section{Cross-Sections Used in WSPRO Analysis}

\begin{tabular}{cccl}
\hline${ }^{1}$ Cross-section & $\begin{array}{c}\text { Section } \\
\text { Reference } \\
\text { Distance } \\
\text { (SRD) } \text { in feet }\end{array}$ & $\begin{array}{c}{ }^{2} \text { Cross-section } \\
\text { development }\end{array}$ & \multicolumn{1}{c}{ Comments } \\
\hline EXITX & -118 & 1 & $\begin{array}{l}\text { Exit section } \\
\text { Downstream Full-valley } \\
\text { section (Templated from } \\
\text { EXITX) }\end{array}$ \\
FULLV & 0 & 2 & $\begin{array}{l}\text { Bridge section } \\
\text { RRIDG }\end{array}$ \\
RDWAY & 0 & 1 & $\begin{array}{l}\text { Road Grade section } \\
\text { Modelled Approach sec- } \\
\text { tion (Templated from } \\
\text { APTEM) }\end{array}$ \\
APPRO & 156 & 1 & $\begin{array}{l}\text { Approach section as sur- } \\
\text { veyed (Used as a tem- } \\
\text { plate) }\end{array}$ \\
\hline
\end{tabular}

${ }^{1}$ For location of cross-sections see plan-view sketch included with Level I field form, Appendix E.

For more detail on how cross-sections were developed see WSPRO input file. 


\section{Data and Assumptions Used in WSPRO Model}

Hydraulic analyses of the reach were done by use of the Federal Highway Administration's WSPRO step-backwater computer program (Shearman and others, 1986, and Shearman, 1990). The analyses reported herein reflect conditions existing at the site at the time of the study. Furthermore, in the development of the model it was necessary to assume no accumulation of debris or ice at the site. Results of the hydraulic model are presented in the Bridge Hydraulic Summary, Appendix B, and figure 7.

Channel roughness factors (Manning's " $n$ ") used in the hydraulic model were estimated using field inspections at each cross section following the general guidelines described by Arcement and Schneider (1989). Final adjustments to the values were made during the modelling of the reach. Channel " $\mathrm{n}$ " values for the reach ranged from 0.035 to 0.040 , and overbank " $\mathrm{n}$ " values ranged from 0.040 to 0.050 .

Normal depth at the exit section (EXITX) was assumed as the starting water surface. This depth was computed by use of the slope-conveyance method outlined in the user's manual for WSPRO (Shearman, 1990). The slope used was $0.001 \mathrm{ft} / \mathrm{ft}$. The slope was estimated from the 100-year discharge water surface profile slope downstream of the site presented in the Flood Insurance Study for Springfield, VT (FEMA, June 1979).

The surveyed approach section (APTEM) was moved along the approach channel slope $(0.004 \mathrm{ft} / \mathrm{ft})$ to establish the modelled approach section (APPRO), one bridge length upstream of the upstream face as recommended by Shearman and others (1986). This location also provides a consistent method for determining scour variables. 


\section{Bridge Hydraulics Summary}

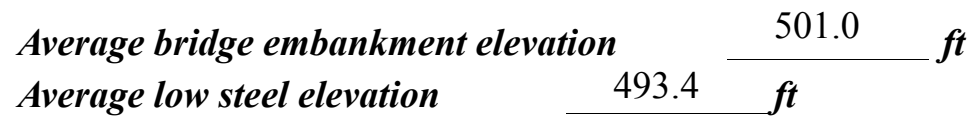

$$
\text { 100-year discharge } \quad 6,940 \quad \mathrm{ft}^{3} / \mathrm{s}
$$

Water-surface elevation in bridge opening

$492.9 \boldsymbol{f t}$

Road overtopping? ___ No Discharge over road __ ${ }_{--}, \ldots$

Area of flow in bridge opening $\quad 1166 \quad \mathrm{ft}^{2}$

Average velocity in bridge opening $\quad 6.0 \mathrm{ft} / \mathrm{s}$

Maximum WSPRO tube velocity at bridge $\quad 7.6 \mathrm{ft} / \mathrm{s}$

Water-surface elevation at Approach section with bridge 493.0

Water-surface elevation at Approach section without bridge

Amount of backwater caused by bridge

$\mathrm{N} / \mathrm{A}$. $t$

500-year discharge $\quad 9,910 \quad \mathrm{ft}^{3} / \mathrm{s}$

Water-surface elevation in bridge opening

$494.5 f t$

Road overtopping? ___ No Discharge over road __ - _ $\quad .3 / 5$

Area of flow in bridge opening $\quad 1226 \quad \mathrm{ft}^{2}$

Average velocity in bridge opening $8.1 \mathrm{ft} / \mathrm{s}$

Maximum WSPRO tube velocity at bridge $\quad 9.2$ _s

Water-surface elevation at Approach section with bridge 496.4

Water-surface elevation at Approach section without bridge $\quad 495.3$

Amount of backwater caused by bridge 1.1 .

Incipient overtopping discharge ___ -- $\mathrm{ft}^{3} / \mathrm{s}$

Water-surface elevation in bridge opening $\quad--\quad t$

Area of flow in bridge opening _ _- $\mathrm{ft}^{2}$

Average velocity in bridge opening __ -- $f t / s$

Maximum WSPRO tube velocity at bridge _-- $f t / s$

Water-surface elevation at Approach section with bridge

Water-surface elevation at Approach section without bridge

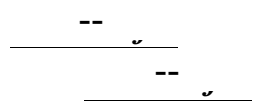

Amount of backwater caused by bridge _ 


\section{Scour Analysis Summary}

\section{Special Conditions or Assumptions Made in Scour Analysis}

Scour depths were computed using the general guidelines described in Hydraulic Engineering Circular 18 (Richardson and others, 1995). Scour depths were calculated assuming an infinite depth of erosive material and a homogeneous particle-size distribution. The results of the scour analysis are presented in tables 1 and 2 and a graph of the scour depths is presented in figure 8 .

Contraction scour for the 100-year discharge was computed by use of Laursen's clear water scour equation (Richardson and others, 1995, p. 32, equation 20). The 500-year discharge resulted in submerged orifice flow. Contraction scour at bridges with orifice flow is best estimated by use of the Chang pressure-flow scour equation (oral communication, J. Sterling Jones, October 4, 1996). Hence, the 500-year event contraction scour depth was computed by use of the Chang equation (Richarson and others, 1995, p. 145-146). The results of Laursen's contraction scour equation for the 500-year event were also computed for comparison and can be found in appendix F.

Abutment scour for the 500-year event was computed by use of the Froehlich equation (Richardson and others, 1995, p. 48, equation 28). Variables for the Froehlich equation include the Froude number of the flow approaching the embankments, the length of the embankment blocking flow, and the depth of flow approaching the embankment less any roadway overtopping.

For the 100-year model, the top width of the water surface in the surveyed approach section is 3.6 feet narrower than in the bridge section. Thus, the abutments are not diverting flow into the main channel. This makes computation of abutment scour impossible. In accordance with the Froehlich equation factor of safety (Richardson and others, 1995, p. 48, equation 28), abutment scour was set equal to the depth of flow at the abutments. 


\section{Scour Results}

\section{0-yr discharge 500-yr discharge}

Contraction scour:

(Scour depths in feet)

Main channel

Live-bed scour

Clear-water scour

Depth to armoring

Left overbank

Right overbank

Local scour:

Abutment scour

Left abutment

Right abutment

Pier scour

Pier 1

Pier 2

Pier 3
11.0

$6.5-$
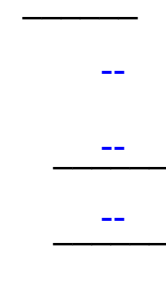

9.9

$11.2-$
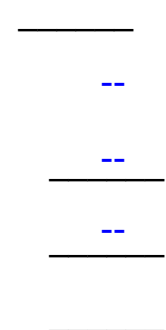

Incipient overtopping discharge

\section{Riprap Sizing}

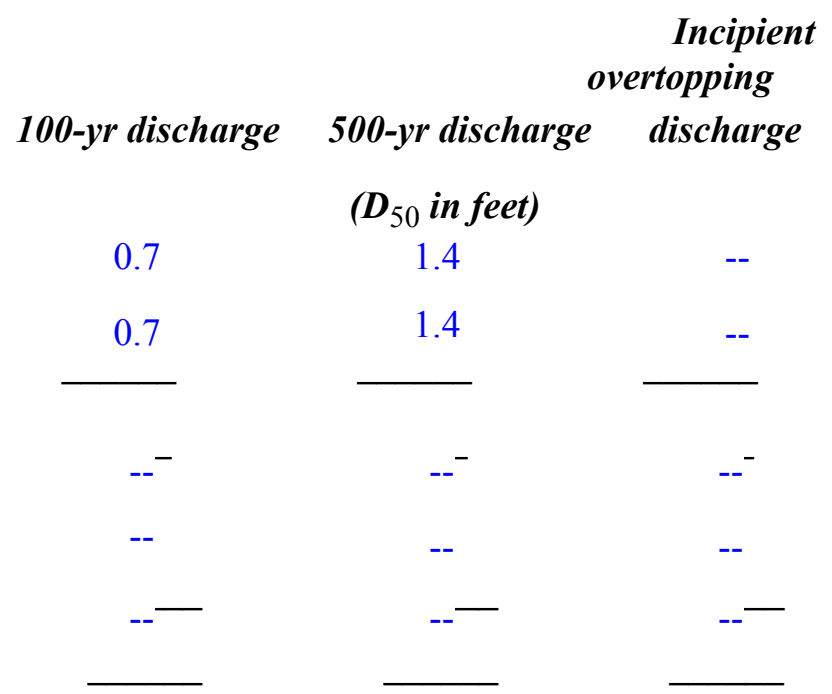




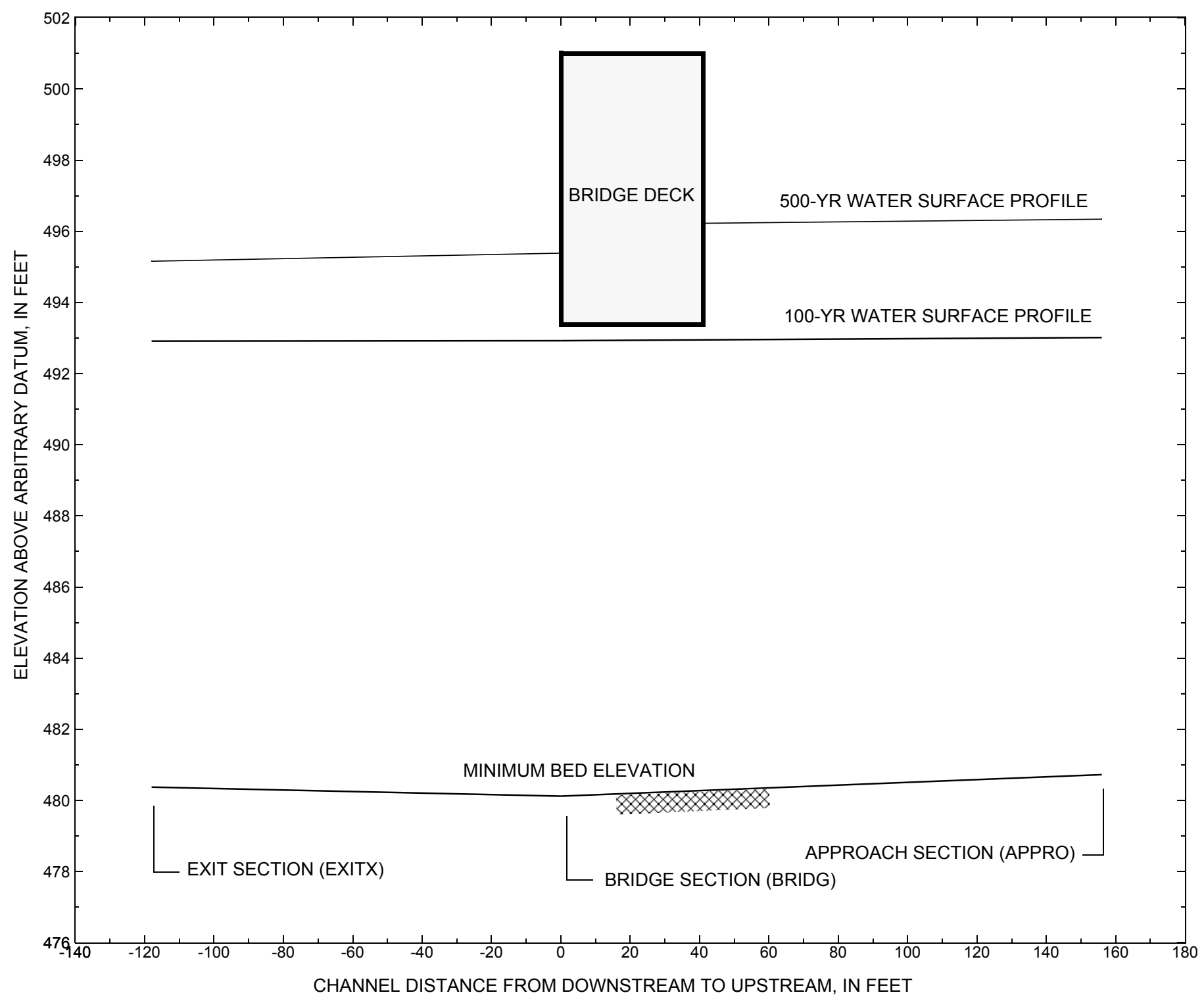

Figure 7. Water-surface profiles for the 100- and 500-yr discharges at structure SPRICYBRIG0043 on Bridge Street, crossing the Black River, Springfield, Vermont. 


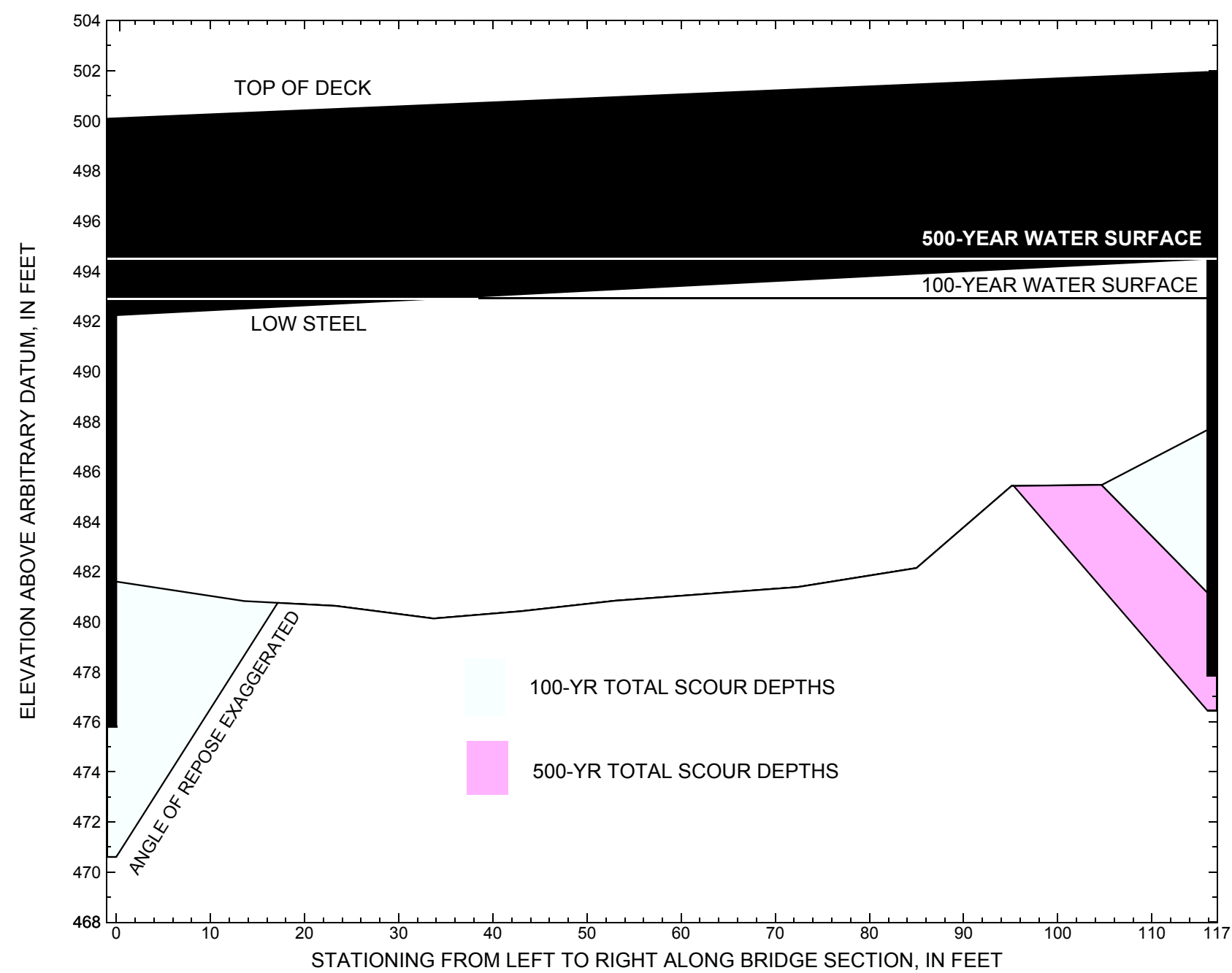

Figure 8. Scour elevations for the 100-yr and 500-yr discharges at structure SPRICYBRIG0043 on Bridge Street, crossing Black River, Springfield, Vermont. 
Table 1. Remaining footing/pile depth at abutments for the 100-year discharge at structure SPRICYBRIG0043 on Bridge Street, crossing the Black River, Springfield, Vermont.

[VTAOT, Vermont Agency of Transportation; --,no data]

\begin{tabular}{|c|c|c|c|c|c|c|c|c|c|c|c|}
\hline Description & Station $^{1}$ & $\begin{array}{c}\text { VTAOT } \\
\text { bridge seat } \\
\text { elevation } \\
\text { (feet) }\end{array}$ & $\begin{array}{c}\text { Surveyed } \\
\text { minimum } \\
\text { low-chord } \\
\text { elevation }{ }^{2} \\
\text { (feet) }\end{array}$ & $\begin{array}{c}\text { Bottom of } \\
\text { footing } \\
\text { elevation } \\
\text { (feet) }\end{array}$ & $\begin{array}{c}\text { Channel } \\
\text { elevation at } \\
\text { abutment/ } \\
\text { pier }^{2} \\
\text { (feet) }\end{array}$ & $\begin{array}{l}\text { Contraction } \\
\text { scour depth } \\
\text { (feet) }\end{array}$ & $\begin{array}{l}\text { Abutment } \\
\text { scour } \\
\text { depth } \\
\text { (feet) }\end{array}$ & $\begin{array}{l}\text { Pier } \\
\text { scour } \\
\text { depth } \\
\text { (feet) }\end{array}$ & $\begin{array}{l}\text { Depth of } \\
\text { total scour } \\
\text { (feet) }\end{array}$ & $\begin{array}{c}\text { Elevation of } \\
\text { scour }^{2} \\
\text { (feet) }\end{array}$ & $\begin{array}{c}\text { Remaining } \\
\text { footing/pile } \\
\text { depth } \\
\text { (feet) }\end{array}$ \\
\hline \multicolumn{12}{|c|}{100 -yr. discharge is 6,940 cubic-feet per second } \\
\hline Left abutment & 0.0 & 330.1 & 492.2 & 475.8 & 481.6 & 0.0 & 11.0 & -- & 11.0 & 470.6 & -5.2 \\
\hline Right abutment & 115.9 & 332.3 & 494.5 & 477.8 & 487.6 & 0.0 & 6.5 & -- & 6.5 & 481.1 & 3.3 \\
\hline
\end{tabular}

1.Measured along the face of the most constricting side of the bridge.

2.Arbitrary datum for this study.

Table 2. Remaining footing/pile depth at abutments for the 500-year discharge at structure SPRICYBRIG0043 on Bridge Street, crossing the Black River, Springfield, Vermont.

[VTAOT, Vermont Agency of Transportation; --, no data]

\begin{tabular}{|c|c|c|c|c|c|c|c|c|c|c|c|}
\hline Description & Station $^{1}$ & $\begin{array}{l}\text { VTAOT } \\
\text { bridge seat } \\
\text { elevation } \\
\text { (feet) }\end{array}$ & $\begin{array}{c}\text { Surveyed } \\
\text { minimum } \\
\text { low-chord } \\
\text { elevation } \\
\text { (feet) }\end{array}$ & $\begin{array}{c}\text { Bottom of } \\
\text { footing } \\
\text { elevation } \\
\text { (feet) }\end{array}$ & $\begin{array}{c}\text { Channel } \\
\text { elevation at } \\
\text { abutment/ } \\
\text { pier }^{2} \\
\text { (feet) }\end{array}$ & $\begin{array}{l}\text { Contraction } \\
\text { scour depth } \\
\text { (feet) }\end{array}$ & $\begin{array}{l}\text { Abutment } \\
\text { scour } \\
\text { depth } \\
\text { (feet) }\end{array}$ & $\begin{array}{l}\text { Pier } \\
\text { scour } \\
\text { depth } \\
\text { (feet) }\end{array}$ & $\begin{array}{l}\text { Depth of } \\
\text { total scour } \\
\text { (feet) }\end{array}$ & $\begin{array}{c}\text { Elevation of } \\
\text { scour }^{2} \\
\text { (feet) }\end{array}$ & $\begin{array}{c}\text { Remaining } \\
\text { footing/pile } \\
\text { depth } \\
\text { (feet) }\end{array}$ \\
\hline \multicolumn{12}{|c|}{500 -yr. discharge is 9,910 cubic-feet per second } \\
\hline Left abutment & 0.0 & 330.1 & 492.2 & 475.8 & 481.6 & 0.0 & 9.9 & -- & 9.9 & 471.7 & -4.1 \\
\hline Right abutment & 115.9 & 332.3 & 494.5 & 477.8 & 487.6 & 0.0 & 11.2 & -- & 11.2 & 476.4 & -1.4 \\
\hline
\end{tabular}

1.Measured along the face of the most constricting side of the bridge.

2.Arbitrary datum for this study. 


\section{SELECTED REFERENCES}

Arcement, G.J., Jr., and Schneider, V.R., 1989, Guide for selecting Manning's roughness coefficients for natural channels and flood plains: U.S. Geological Survey Water-Supply Paper 2339, 38 p.

Barnes, H.H., Jr., 1967, Roughness characteristics of natural channels: U.S. Geological Survey Water-Supply Paper 1849,213 p.

Benson, M. A., 1962, Factors Influencing the Occurrence of Floods in a Humid Region of Diverse Terrain: U.S. Geological Survey Water-Supply Paper 1580-B, 64 p.

Brown, S.A. and Clyde, E.S., 1989, Design of riprap revetment: Federal Highway Administration Hydraulic Engineering Circular No. 11, Publication FHWA-IP-89-016, 156 p.

Federal Highway Administration, 1983, Runoff estimates for small watersheds and development of sound design: Federal Highway Administration Report FHWA-RD-77-158

Federal Emergency Management Agency, 1980, Flood Insurance Study, Town of Springfield, Windsor County, Vermont: Washington, D.C., June 1979.

Froehlich, D.C., 1989, Local scour at bridge abutments in Ports, M.A., ed., Hydraulic Engineering--Proceedings of the 1989 National Conference on Hydraulic Engineering: New York, American Society of Civil Engineers, p. 13-18.

Hayes, D.C.,1993, Site selection and collection of bridge-scour data in Delaware, Maryland, and Virginia: U.S. Geological Survey Water-Resources Investigation Report 93-4017, 23 p.

Interagency Advisory Committee on Water Data, 1982, Guidelines for determining flood flow frequency: U.S. Geological Survey, Bulletin 17B of the Hydrology Subcommittee, 190 p.

Johnson, C.G. and Tasker, G.D.,1974, Progress report on flood magnitude and frequency of Vermont streams: U.S. Geological Survey Open-File Report 74-130, 37 p.

Lagasse, P.F., Schall, J.D., Johnson, F., Richardson, E.V., Chang, F., 1995, Stream Stability at Highway Structures: Federal Highway Administration Hydraulic Engineering Circular No. 20, Publication FHWA-IP-90-014, 144 p.

Laursen, E.M., 1960, Scour at bridge crossings: Journal of the Hydraulics Division, American Society of Civil Engineers, v. 86, no. HY2, p. 39-53.

Potter, W. D., 1957a, Peak rates of runoff in the Adirondack, White Mountains, and Maine woods area, Bureau of Public Roads

Potter, W. D., 1957b, Peak rates of runoff in the New England Hill and Lowland area, Bureau of Public Roads

Richardson, E.V. and Davis, S.R., 1995, Evaluating scour at bridges: Federal Highway Administration Hydraulic Engineering Circular No. 18, Publication FHWA-IP-90-017, 204 p.

Richardson, E.V., Simons, D.B., and Julien, P.Y., 1990, Highways in the river environment: Federal Highway Administration Publication FHWA-HI-90-016.

Ritter, D.F., 1984, Process Geomorphology: W.C. Brown Co., Debuque, Iowa, 603 p.

Shearman, J.O., 1990, User's manual for WSPRO--a computer model for water surface profile computations: Federal Highway Administration Publication FHWA-IP-89-027, 187 p.

Shearman, J.O., Kirby, W.H., Schneider, V.R., and Flippo, H.N., 1986, Bridge waterways analysis model; research report: Federal Highway Administration Publication FHWA-RD-86-108, 112 p.

Talbot, A.N., 1887, The determination of water-way for bridges and culverts.

U.S. Department of Transportation, 1993, Stream stability and scour at highway bridges, Participant Workbook: Federal Highway Administration Publication FHWA HI-91-011.

U.S. Geological Survey, 1984, Springfield, Vermont 7.5 Minute Series quadrangle map: U.S. Geological Survey Topographic Maps, Scale $1: 25,000$. 


\section{APPENDIX A: \\ WSPRO INPUT FILE}




\section{WSPRO INPUT FILE}

$\mathrm{Q}$

SK

*

$\mathrm{XS}$

GR

GR

GR

GR

GR

GR

$\mathrm{N}$

SA

*

X

*

BR

GR

GR

GR

GR

*

CD

$\mathrm{N}$

*

*

$\mathrm{XR}$

GR

GR

*

$\mathrm{XT}$

GR

GR

GR

GR

*

AS

GT

$\mathrm{N}$

SA

*

HP 1 BRIDG

HP 2 BRIDG

HP 1 APPRO

HP 2 APPRO

*

HP 1 BRIDG

HP 2 BRIDG

HP 1 APPRO

RDWAY
U.S. Geological Survey WSPRO Input File spri043.wsp

Hydraulic analysis for structure SPRICYBRIG0043 Date: 24-JAN-97

Bridge \# 43 on Bridge street over the Black River in springfield, VT

* $* 0.002$

$\begin{array}{lllllllllllllllllllll}6 & 29 & 30 & 552 & 553 & 551 & 5 & 16 & 17 & 13 & 3 & * & 15 & 14 & 23 & 21 & 11 & 12 & 4 & 7 & 3\end{array}$

$6940.0 \quad 9910.0$

$0.0010 \quad 0.0010$

$\operatorname{EXITX}-118$

$-578.3,516.66-534.4,511.23$

$-456.5,504.97$

$-209.6,495.07$

$-99.4,494.59$

$0.0,493.66$

$16.3,483.16$

$21.1,481.95$

$27.0,481.22$

$40.1,480.79$

$48.3,481.35$

$65.1,480.65$

$76.3,480.37$

$90.0,481.29$

$96.3,482.05$

$106.7,483.84$

$170.1,498.01$

$403.4,498.72$

$138.6,488.23 \quad 154.1,495.16$

$614.0,512.31$

0.040

0.040

0.050

$0.0 \quad 154.1$

FULLV

$0 * * *$

0.0009

\section{SRD LSEL XSSKEW}

$\begin{array}{lll}0 & 493.37 & 20.0\end{array}$

$0.0,492.24 \quad 0.0,481.60$

$33.7,480.12$

$85.0,482.14$

$115.9 ， 494.49$

BRTYPE BRWDTH

156.1 * *

$13.6,480.82$

$23.3,480.63$

$43.0,480.41$

$53.0,480.83$

$72.4,481.38$

$95.1,485.42$

$104.7,485.46$

$115.6,487.65$

$0.0,492.24$

WWANGL WWWID

$67.7 \quad 8.1$

0.035

SRD EMBWID IPAVE

$2341.0 \quad 1$

$167.7,500.86$

$0.0,500.10$

$116.4,501.95$

$167.7,501.45$

$474.1,497.28$

$476.4,502.77$

$491.8,509.36$

In FEMA study, flow was not found to leave the left bank

$\begin{array}{rrrrr}0.0,499.63 & 23.2,484.21 & 28.1,482.82 & 33.3,481.52 \\ 54.9,481.28 & 63.6,480.77 & 75.3,481.75 & 82.3,481.65 \\ 98.4,481.80 & 102.1,482.75 & 117.8,495.21 & 157.6,499.20 \\ 357.5,499.21 & 479.4,497.29 & 493.5,508.95 & \end{array}$

$357.5,499.21 \quad 479.4,497.29 \quad 493.5,508.95$

156

$-0.053$

0.050

0.040

157.6

0.050

492.921492 .92

492.92 * * 6940

493.011493 .01

$493.01 * * 6940$

494.491494 .49

494.49 * * 9910

496.381496 .38 


\section{APPENDIX B: \\ WSPRO OUTPUT FILE}


WSPRO OUTPUT FILE

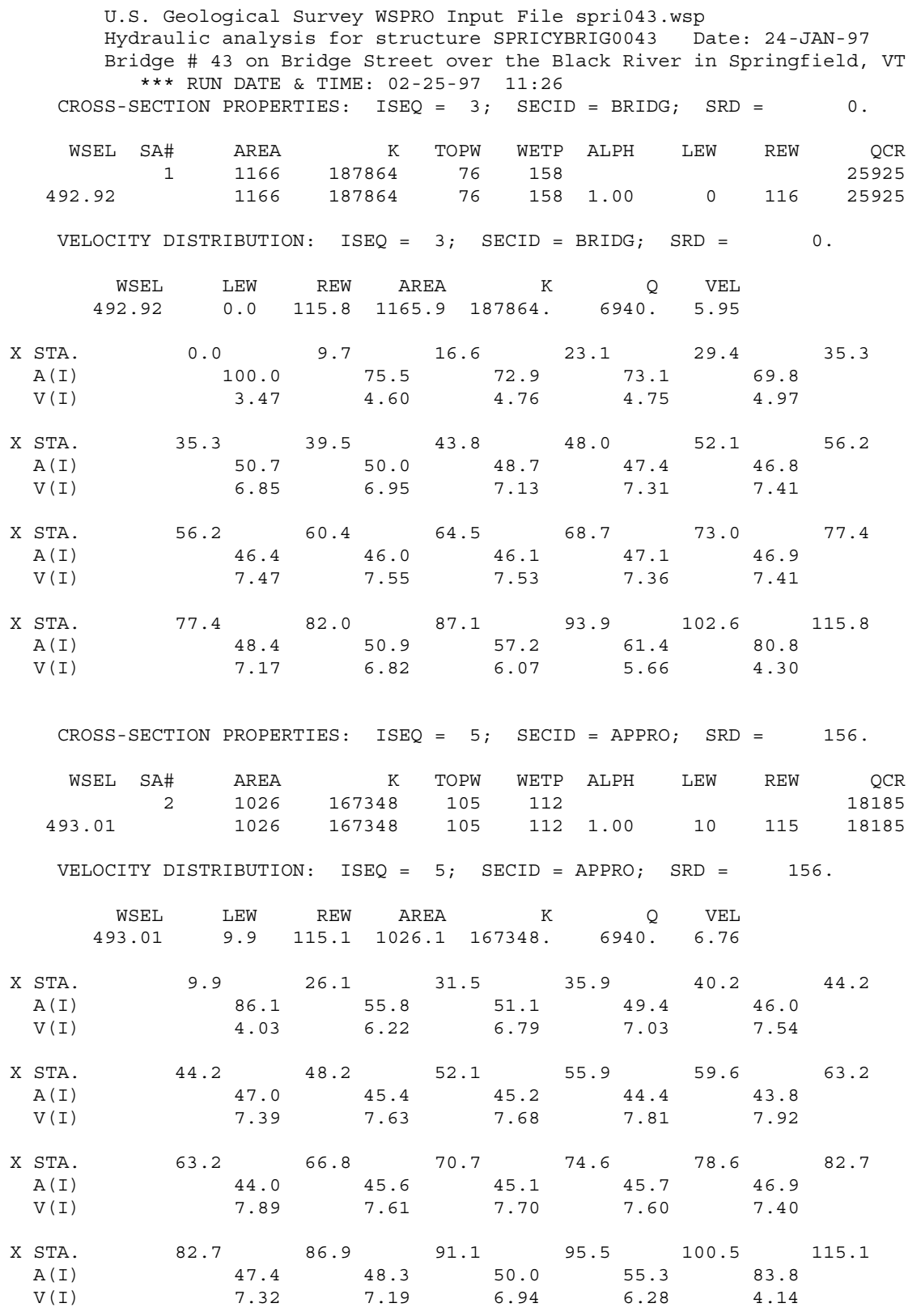


WSPRO OUTPUT FILE (continued)

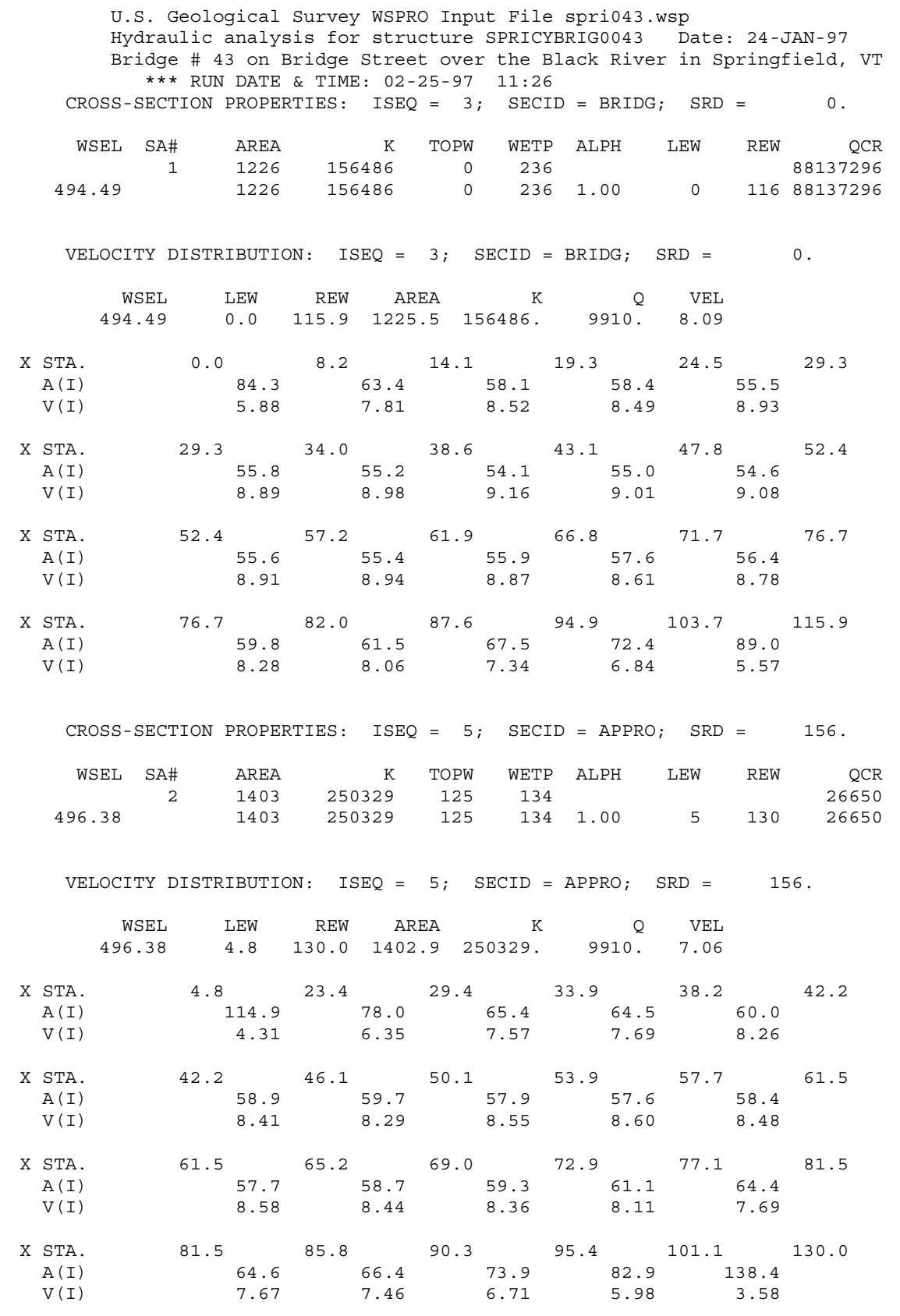


WSPRO OUTPUT FILE (continued)

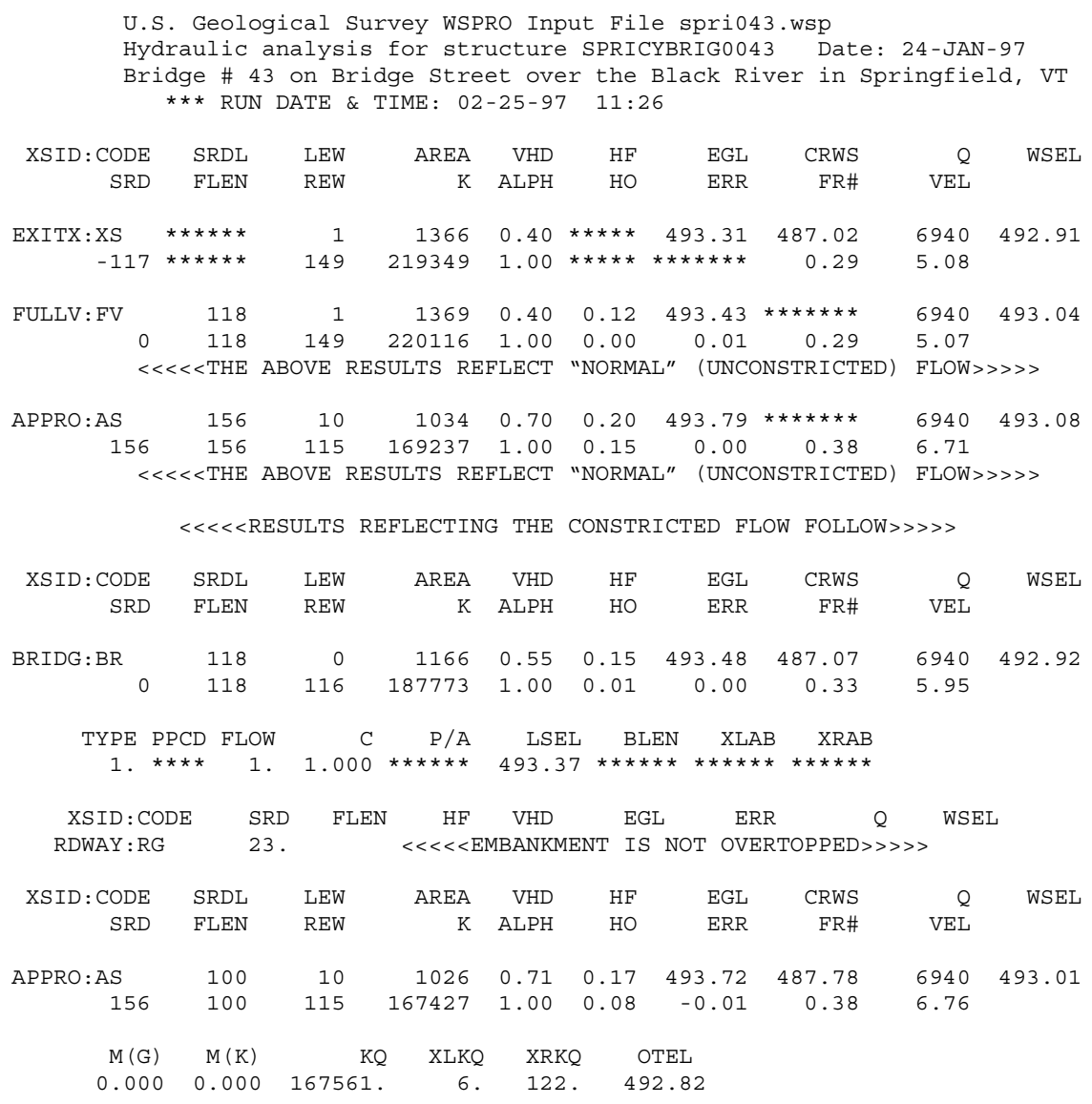

FIRST USER DEFINED TABLE.

\begin{tabular}{|c|c|c|c|c|c|c|c|c|}
\hline XSID : CODE & SRD & LEW & REW & Q & $\mathrm{K}$ & AREA & VEL & WSEL \\
\hline EXITX:XS & -118 & 1 . & 149 . & 6940. & 219349 . & 1366. & 5.08 & 492.91 \\
\hline FULLV : FV & 0 . & 1. & 149. & 6940. & 220116 . & 1369. & 5.07 & 493.04 \\
\hline BRIDG : BR & 0 . & 0 . & 116. & 6940. & 187773. & 1166. & 5.95 & 492.92 \\
\hline RDWAY : RG & \multicolumn{3}{|c|}{$23 . * \star \star * \star * \star * * \star * \star * \star * *$} & \multicolumn{3}{|c|}{ 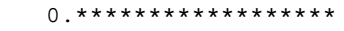 } & \multicolumn{2}{|c|}{$1.00 * * * * * * * *$} \\
\hline APPRO : AS & 156. & 10. & 115. & 6940. & 167427. & 1026 . & 6.76 & 493.01 \\
\hline XSID : CODE & XLKQ & $\mathrm{XRKQ}$ & & & & & & \\
\hline APPRO: AS & 6 . & 122 . & $16756]$ & & & & & \\
\hline
\end{tabular}

SECOND USER DEFINED TABLE.

\begin{tabular}{|c|c|c|c|c|c|c|c|c|c|}
\hline XSID : CODE & CRWS & FR\# & YMIN & YMAX & $\mathrm{HF}$ & $\mathrm{HO}$ & VHD & EGL & WSEL \\
\hline EXITX:XS & 487.02 & 0.29 & 480.37 & $516.66 *$ & 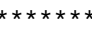 & 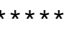 & 0.40 & 493.31 & 492.91 \\
\hline FULLV : FV & $\star \star \star \star * \star * \star * *$ & 0.29 & 480.48 & 516.77 & 0.12 & 0.00 & 0.40 & .43 & 493.04 \\
\hline BRIDG : BR & 487.07 & 0.33 & 480.12 & 494.49 & 0.15 & 0.01 & 0.55 & 493.48 & 492.92 \\
\hline : RG & $\star \star \star \star * \star * \star * \star * *$ & $\star \star \star \star \star *$ & 497.28 & $15.40 *$ & $\star * * *$ & & & & 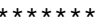 \\
\hline PPRO : AS & 487.78 & 0.38 & 480.72 & 508.90 & 0.17 & 0.08 & 71 & 493 & 493 \\
\hline
\end{tabular}


WSPRO OUTPUT FILE (continued)

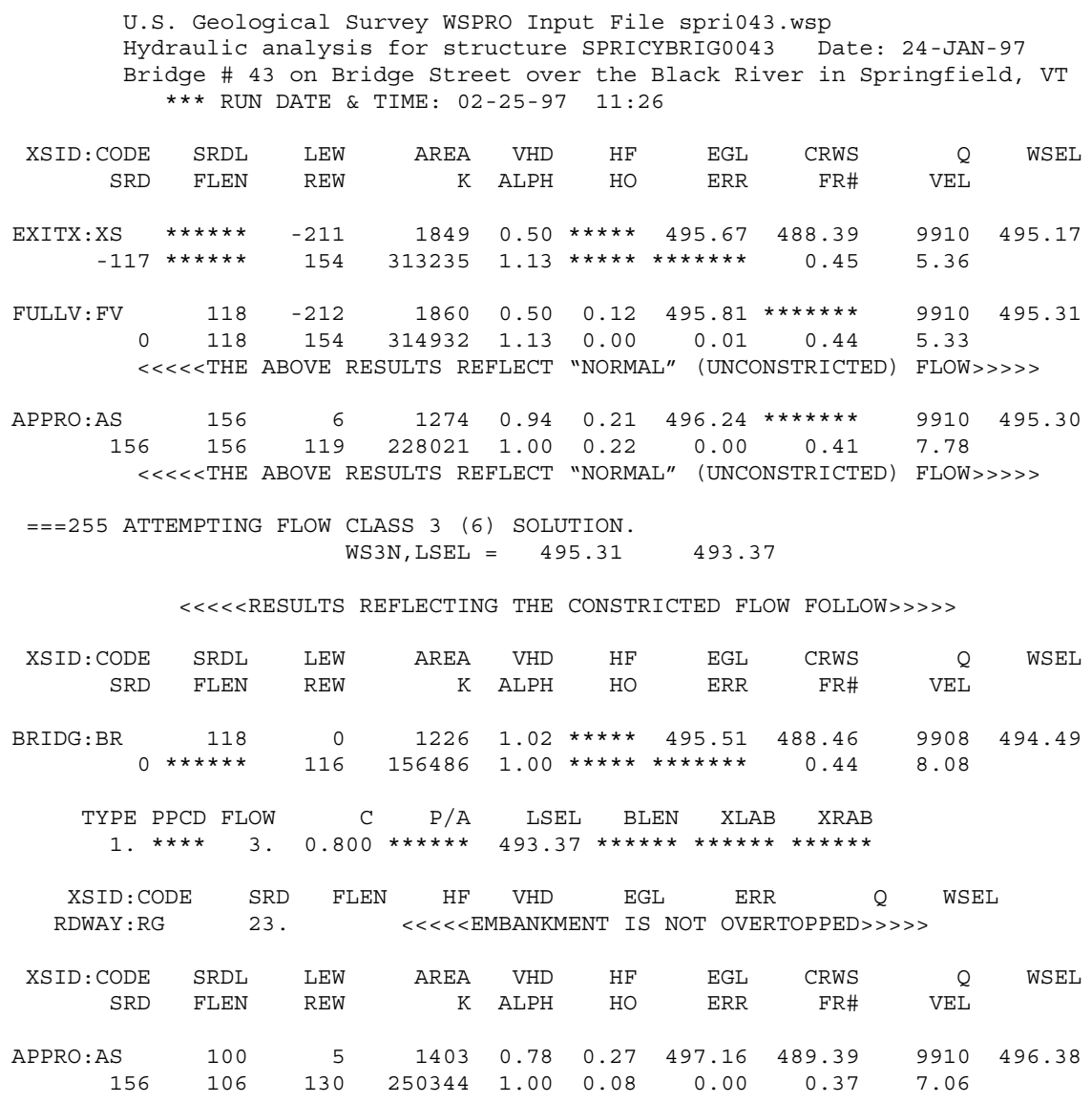

FIRST USER DEFINED TABLE.

\begin{tabular}{|c|c|c|c|c|c|c|c|c|}
\hline XSID : CODE & SRD & LEW & REW & $Q$ & $\mathrm{~K}$ & AREA & VEL & WSEL \\
\hline EXITX:XS & -118. & -212. & 154. & 9910. & 313235 . & 1849. & 5.36 & 495.17 \\
\hline FULLV: FV & 0 . & -213. & 154. & 9910. & 314932 . & 1860. & 5.33 & 495.31 \\
\hline BRIDG : BR & 0 . & 0 . & 116. & 9908. & 156486 . & 1226. & 8.08 & 494.49 \\
\hline RDWAY : RG & 23. & $* \star \star \star \star * x$ & $\star \star \star \star *$ & 0 . & & $\star \star \star \star *$ & 1.00 & 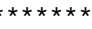 \\
\hline APPRO: AS & 156. & 5. & 130. & 9910. & 250344 . & 1403. & 7.06 & 496.38 \\
\hline
\end{tabular}

SECOND USER DEFINED TABLE.

\begin{tabular}{|c|c|c|c|c|c|c|c|c|c|}
\hline XSID : CODE & CRWS & FR\# & YMIN & YMAX & $\mathrm{HF}$ & $\mathrm{HO}$ & VHD & EGL & WSEL \\
\hline EXITX:XS & 488.39 & 0.45 & 480.37 & 516.66 * & $\approx * \star \star \star \star \star *$ & $* \star \star \star * *$ & 0.50 & 495.67 & 495.17 \\
\hline FULLV : FV & $\star * \star \star * \star * * *$ & 0.44 & 480.48 & 516.77 & 0.12 & 0.00 & 0.50 & 495.81 & 495.31 \\
\hline BRIDG : BR & 488.46 & 0.44 & 480.12 & $494.49 *$ & $* * * * * * *$ & $* \star \star \star * *$ & 1.02 & 495.51 & 494.49 \\
\hline RDWAY : RG & 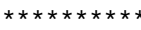 & $* \star \star \star \star *$ & 497.28 & $515.40 *$ & 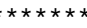 & $* * \star * *$ & 0.51 & $499.09 x$ & 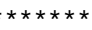 \\
\hline APPRO:AS & 489.39 & 0.37 & 480.72 & 508.90 & 0.27 & 0.08 & 0.78 & 497.16 & 496.38 \\
\hline
\end{tabular}




\section{APPENDIX C:}

\section{BED-MATERIAL PARTICAL-SIZE DISTRIBUTION}




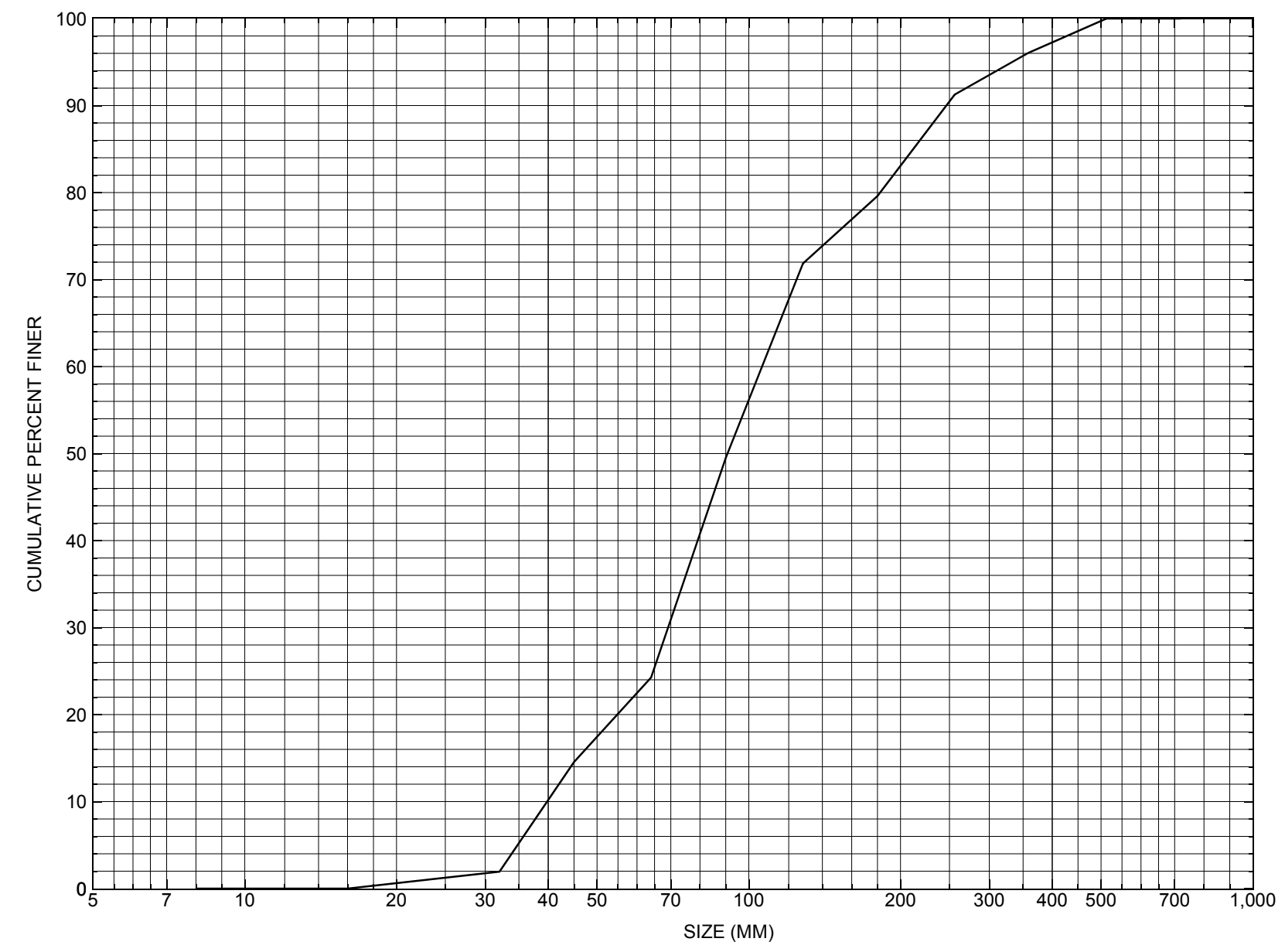

Appendix C. Bed material particle-size distribution for a pebble count in the channel approach of structure SPRICYBRIG0043, in Springfield, Vermont. 


\section{APPENDIX D: \\ HISTORICAL DATA FORM}




\section{Structure Number SPRICYBRIG0043}

\section{General Location Descriptive}

Data collected by (First Initial, Full last name) $\mathbf{E}$. BOEHMLER

Date $(M M / D D / Y Y) \_\mathbf{0 3} / \underline{\mathbf{3 0} /} \mathbf{9 5}$

Highway District Number (I - 2; nn) $\mathbf{0 2}$

Town (FIPS place code; I - 4; nnnnn) $\mathbf{6 9 4 7 5}$

Waterway (I - 6) BLACK RIVER

Route Number -

Topographic Map Springfield

Latitude (I - 16; nnnn.n) $\mathbf{4 3 1 7 8}$
County (FIPS county code; I - 3; nnn)

Mile marker (I - 11; nnn.nnn) $\mathbf{0 0 0 0 8 0}$

Road Name (I - 7): BRIDGE STREET

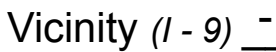

Hydrologic Unit Code: $\mathbf{0 1 0 8 0 1 0 6}$

Longitude (i - 17; nnnnn.n) $\mathbf{7 2 2 8 5}$

\section{Select Federal Inventory Codes}

FHWA Structure Number (I - 8) $\mathbf{2 0 2 5 0 2 0 0 4 3 1 4 1 8}$

Maintenance responsibility $(I-21 ; n n)$

Year built (I - 27; YYYY) 1988

Average daily traffic, ADT (I - 29; nnnnnn) 002490

Year of ADT (I - 30; YY) $\mathbf{8 9}$

Opening skew to Roadway $(I-34 ; n n) \quad 18$

Operational status $(I-41 ; X) \quad \mathbf{A}$

Structure type (I - 43; nnn) $\mathbf{3 0 2}$

Approach span structure type $(I-44 ; n n n) \quad \mathbf{0 0 0}$

Number of spans (I - 45; nnn) $\mathbf{0 0 1}$

Number of approach spans (I - 46; nnnn) $\mathbf{0 0 0 0}$

Comments:

The structural inspection report of 8/24/94 indicates the structure is a steel stringer type bridge with a concrete deck and an asphalt roadway surface. The abutment walls and wingwalls are concrete, which are reported in "like-new" condition. There is an older concrete abutment just upstream from the current left abutment, which has some random heavy spalling. The waterway is noted as making a very slight bend into the crossing. The streambed consists of stone and gravel. There is some stone fill noted along the right abutment. The abutment footings are reported as not exposed. Channel scour, streambank erosion, point bars, and debris accumulation problems are all reported as not evident at this site. 


\section{Bridge Hydrologic Data}

Is there hydrologic data available? $\underline{\mathbf{Y}}$ if No, type ctrl-n $h \quad$ VTAOT Drainage area $\left(m i^{2}\right): \underline{\mathbf{1 8 9 . 3}}$ Terrain character: Mountainous to rolling

Stream character \& type: Mountainous and a tributary to the Connecticut River.

Streambed material: Sandy Gravel

Discharge Data (cfs): $\quad \mathrm{Q}_{2.33} \underline{\mathbf{2 0 0 0}}$

$\mathrm{Q}_{50} \mathbf{5 2 0 0}$

$\begin{array}{ll}Q_{10} \frac{3500}{690} & Q_{25} \stackrel{4400}{-} \\ Q_{100} & \mathbf{6 9 0 0}\end{array}$

Record flood date $(M M / D D / Y Y)$ : - $/ / / 27$ Water surface elevation (ft): -

Estimated Discharge (cfs): __ Velocity at Q $\underline{25}$ (ft/s): $\underline{\mathbf{6 . 7}}$

Ice conditions (Heavy, Moderate, Light): Moderate Debris (Heavy, Moderate, Light): Moderate

The stage increases to maximum highwater elevation (Rapidly, Not rapidly): Not rapidly

The stream response is (Flashy, Not flashy): Not flashy

Describe any significant site conditions upstream or downstream that may influence the stream's stage: -

Watershed storage area (in percent): 1

The watershed storage area is: $\mathbf{2}$ (1-mainly at the headwaters; 2- uniformly distributed; 3-immediatly upstream oi the site)

Water Surface Elevation Estimates for Existing Structure:

\begin{tabular}{|l|l|l|l|l|l|}
\hline Peak discharge frequency & $Q_{2.33}$ & $Q_{10}$ & $Q_{25}$ & $Q_{50}$ & $Q_{100}$ \\
Water surface elevation $(f t))$ & $\mathbf{3 2 5 . 2}$ & $\mathbf{3 2 7 . 2}$ & $\mathbf{3 2 8 . 2}$ & $\mathbf{3 2 9 . 0}$ & $\mathbf{3 3 0 . 6}$ \\
Velocity $(f t / \mathrm{sec})$ & $\mathbf{4 . 9}$ & $\mathbf{6 . 1}$ & $\mathbf{6 . 6}$ & $\mathbf{7 . 1}$ & $\mathbf{7 . 7}$ \\
\hline
\end{tabular}

Long term stream bed changes: Calculated scour estimated at 2 to 4 feet.

Is the roadway overtopped below the $\mathrm{Q}_{100}$ ? (Yes, No, Unknown): $\mathbf{N} \quad$ Frequency: -

Relief Elevation (ft):

Discharge over roadway at $\mathrm{Q}_{100}\left(f^{3} / \mathrm{sec}\right)$ : -

Are there other structures nearby? (Yes, No, Unknown): $\mathbf{Y}$

Upstream distance (miles): $\mathbf{0 . 7 5}$

Town: Springfield If No or Unknown, type ctrl-n os

Highway No. : VT11 Structure No. : 64 Structure Type:

Clear span (ft): 148. Clear Height (ft): $\underline{\mathbf{2 7 . 0}}$ Full Waterway $\left(f^{2}\right): \underline{\mathbf{4 0 0 0} .}$ 
Downstream distance (miles): 1.1 Town: Springfield Year Built:

Highway No. : TH66 Structure No. : 81 Structure Type:

Clear span (ft): $\underline{152 .}$ Clear Height $(f t): \underline{15.0}$ Full Waterway $\left(\mathrm{ft}^{2}\right): \mathbf{2 2 8 0 .}$

Comments:

Hydraulics report recommends using class II stone fill. The type of foundation indicated is silt and sandy silt material below the bridge footings. Relief over bridge or roadway is not expected for flows less than or equal to the Q100.

\section{USGS Watershed Data}

Watershed Hydrographic Data

Drainage area $(D A) \underline{191.30} \mathrm{mi}^{2}$

Watershed storage (ST) $\quad \mathbf{1 . 2 2}$

Bridge site elevation $\mathbf{3 3 5} \mathrm{ft}$ $\%$

Main channel length $\mathbf{4 1 . 7 9} \mathrm{mi}$

$10 \%$ channel length elevation $\mathbf{4 5 0}$

Lake and pond area

2.33 $\mathrm{mi}^{2}$

Main channel slope

(S) 23.77 $\mathrm{ft} / \mathrm{mi}$

Watershed Precipitation Data

Average site precipitation in Average headwater precipitation in

Maximum 2yr-24hr precipitation event $(124,2)$ in

Average seasonal snowfall (Sn) $\mathrm{ft}$ 


\section{Bridge Plan Data}

Are plans available? $\underline{Y}$ If no, type ctrl-n pl Date issued for construction (MM/YYYY): $\underline{04} / \mathbf{1 9 8 7}$

Project Number $\mathbf{M}$ - 2500 (7)

Minimum channel bed elevation: $\mathbf{3 1 8 . 7}$

Low superstructure elevation: USLAB $\underline{\mathbf{3 3 0 . 6 3}}$ DSLAB $\underline{\mathbf{3 3 0 . 1 1}}$ USRAB $\underline{\mathbf{3 3 2 . 5 1}}$ DSRAB $\underline{\mathbf{3 3 2 . 3 1}}$

Benchmark location description:

There is no specific benchmark information on the plan. Some other points shown with elevations are: 1) the point on the top streamward edge of the upstream right wingwall concrete where the concrete slope changes from horizontal to downward, elevation 340.0, and 2) The point at the same location as in 1) but on the upstream left wingwall, elevation 338.17.

Reference Point (MSL, Arbitrary, Other): Arbitrary _ Datum (NAD27, NAD83, Other): Arbitrary Foundation Type: 1 (1-Spreadfooting; 2-Pile; 3- Gravity; 4-Unknown)

If 1: Footing Thickness $\mathbf{3 . 0} \quad$ Footing bottom elevation: $\underline{\text { 314.0* }}$

If 2: Pile Type: __ (1-Wood; 2-Steel or metal; 3-Concrete) Approximate pile driven length:

If 3: Footing bottom elevation:

Is boring information available? $\underline{\mathbf{Y}}$ If no, type ctrl- $n$ bi Number of borings taken: $\underline{4}$

Foundation Material Type: 1 (1-regolith, 2-bedrock, 3-unknown)

Briefly describe material at foundation bottom elevation or around piles:

Footing of the right abutment is set in sand, gravel and silt (B1 and B2)

Footing of the left abutment is set in silt (B3 upstream end) and silt (B4 center) with bedrock 14.9 feet below the footing base.

Comments:

*The bottom of the left abutment footing is shown at 314.0 left, and that of the right abutment is shown at 316.0. Additional elevation points: the lowest end on the top of the upstream right wingwall, elevation 337.5; The top streamward edge of the downstream right wingwall where the slope begins to decline, elevation 339.9; The lowest end on the top of the downstream right wingwall, elevation 335.0; The lowest point on the top of the upstream left wingwall, elevation 335.6; The top streamward edge of the downstream left wingwall where the slope begins to decline, elevation 337.7; The lowest point on the top of the downstream left wingwall, elevation 334.5. 


\section{Cross-sectional Data}

Is cross-sectional data available? $\underline{\mathbf{Y}}$ If no, type ctrl-n xs

Source (FEMA, VTAOT, Other)? VTAOT

Comments: Several cross section are available. No reproducible bridge face cross sections.

\begin{tabular}{|l|l|l|l|l|l|l|l|l|l|l|l|}
\hline Station & - & - & - & - & - & - & - & - & - & - & - \\
\hline Feature & - & - & - & - & - & - & - & - & - & - & - \\
\hline $\begin{array}{l}\text { Low cord } \\
\text { elevation }\end{array}$ & - & - & - & - & - & - & - & - & - & - & - \\
\hline $\begin{array}{l}\text { Bed } \\
\text { elevation }\end{array}$ & - & - & - & - & - & - & - & - & - & - & - \\
\hline $\begin{array}{l}\text { Low cord to } \\
\text { bed length }\end{array}$ & - & - & - & - & - & - & - & - & - & - & - \\
\hline Station & - & - & - & - & - & - & - & - & - & - & - \\
\hline Feature & - & - & - & - & - & - & - & - & - & - & - \\
\hline $\begin{array}{l}\text { Low cord } \\
\text { elevation }\end{array}$ & - & - & - & - & - & - & - & - & - & - & - \\
\hline $\begin{array}{l}\text { Bed } \\
\text { elevation }\end{array}$ & - & - & - & - & - & - & - & - & - & - & - \\
\hline $\begin{array}{l}\text { Low cord to } \\
\text { bed length }\end{array}$ & - & - & - & - & - & - & - & - & - & - & - \\
\hline
\end{tabular}

Source (FEMA, VTAOT, Other)? FEMA

Comments: FEMA data exists, but its collection predates the bridge construction.

\begin{tabular}{|l|l|l|l|l|l|l|l|l|l|l|l|}
\hline Station & & - & - & - & - & - & - & - & - & - & - \\
\hline Feature & - & - & - & - & - & - & - & - & - & - & - \\
\hline $\begin{array}{l}\text { Low cord } \\
\text { elevation }\end{array}$ & - & - & - & - & - & - & - & - & - & - & - \\
\hline $\begin{array}{l}\text { Bed } \\
\text { elevation }\end{array}$ & - & - & - & - & - & - & - & - & - & - & - \\
\hline $\begin{array}{l}\text { Low cord to } \\
\text { bed length }\end{array}$ & - & - & - & - & - & - & - & - & - & - & - \\
\hline Station & - & - & - & - & - & - & - & - & - & - & - \\
\hline \begin{tabular}{l} 
Feature \\
\hline
\end{tabular} & - & - & - & - & - & - & - & - & - & - \\
\hline $\begin{array}{l}\text { Low cord } \\
\text { elevation }\end{array}$ & - & - & - & - & - & - & - & - & - & - & - \\
\hline $\begin{array}{l}\text { Bed } \\
\text { elevation }\end{array}$ & - & - & - & - & - & - & - & - & - & - & - \\
\hline $\begin{array}{l}\text { Low cord to } \\
\text { bed length }\end{array}$ & - & - & - & - & - & - & - & - & - & - & - \\
\hline
\end{tabular}




\section{APPENDIX E: \\ LEVEL I DATA FORM}


U. S. Geological Survey

Bridge Field Data Collection and Processing Form

Qa/Qc Check by: $\underline{\mathbf{R B}}$ Date: $10 / 17 / 96$

\section{Structure Number SPRICYBRIG0043}

Computerized by: $\underline{\mathbf{R B}}$ Date: $10 / 17 / 96$

Reviewd by: MAI Date: 02/25/97

\section{A. General Location Descriptive}

1. Data collected by (First Initial, Full last name) L. MEDALIE

2. Highway District Number $\mathbf{0 2}$

Mile marker 000080

County WINDSOR (027)

Town SPRINGFIELD (69475)

Waterway (I - 6) BLACK RIVER

Road Name BRIDGE STREET

Route Number -

Hydrologic Unit Code: $\mathbf{0 1 0 8 0 1 0 6}$

3. Descriptive comments:

Located 0.05 miles from the intersection of Bridge Street with VT 11.

\section{B. Bridge Deck Observations}
4. Surface cover... LBUS 1
RBUS 1
LBDS 1
RBDS 1
Overall 1

(2b us, ds,lb,rb: 1- Urban; 2- Suburban; 3- Row crops; 4- Pasture; 5- Shrub- and brushland; 6- Forest; 7- Wetland)
5. Ambient water surface... US 2
UB 1
DS 1
(1- pool; 2- riffle)

6. Bridge structure type 1 (1- single span; 2- multiple span; 3- single arch; 4- multiple arch; 5-cylindrical culvert; 6- box culvert; or 7- other)
7. Bridge length 123
(feet)
Span length 119
(feet)
Bridge width 41 (feet)

\section{Road approach to bridge:}
8. LB 1 RB $\underline{\mathbf{0}}$
( 0 even, 1- lower, 2- higher)
9. LB
RB 1
(1- Paved, 2- Not paved)

10. Embankment slope (run / rise in feet / foot)

$$
\text { US left }
$$

0.0:1

US right

0.0:1

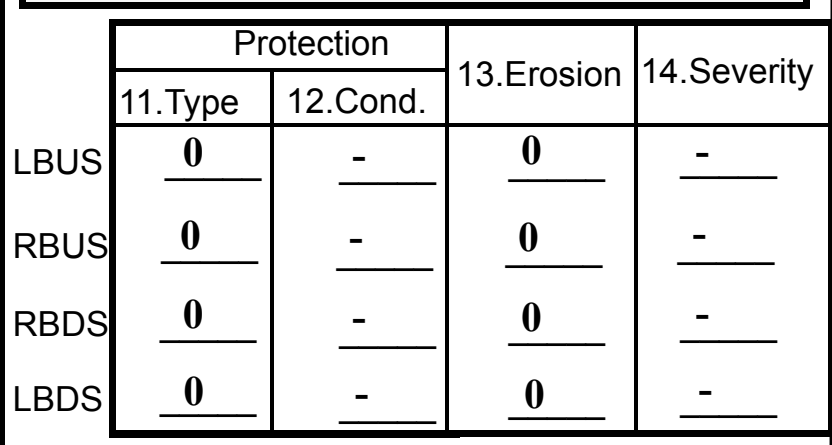

Bank protection types: 0- none; 1- $<12$ inches; 2- < 36 inches; 3- < 48 inches;

4- < 60 inches; 5- wall / artificial levee

Bank protection conditions: 1- good; 2- slumped;

3- eroded; 4- failed

Erosion: 0 - none; 1- channel erosion; 2 -

road wash; 3- both; 4- other

Erosion Severity: 0 - none; 1- slight; 2- moderate; 3- severe

\section{Channel approach to bridge (BF):}

15. Angle of approach: 0

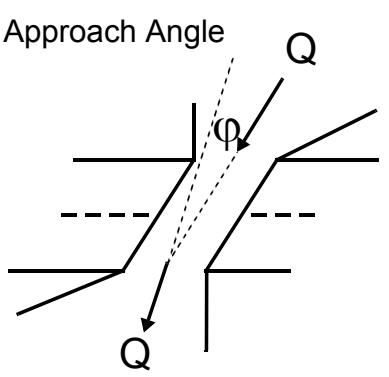

17. Channel impact zone 1 :

Where? LB $(L B, R B)$

Range? 250 feet DS

Channel impact zone 2:

Where? $(L B, R B)$

Range? - $\quad$ feet -

(US, UB, DS) to feet Impact Severity: 0- none to very slight; 1- Slight; 2- Moderate; 3- Severe

16. Bridge skew: 20 Bridge Skew Angle

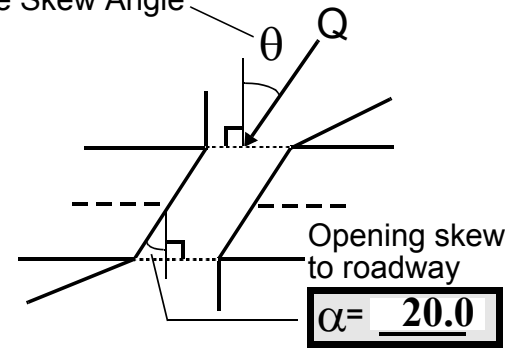

\section{Exist? $\mathbf{Y}(Y$ or $N)$}

Severity 2

(US, UB, DS) to $\underline{480}$ feet $\underline{\text { DS }}$

Exist? $\mathbf{N}(Y$ or $N)$

Severity - 
18. Bridge Type: 1a

1a- Vertical abutments with wingwalls

$1 \mathrm{~b}$ - Vertical abutments without wingwalls

2- Vertical abutments and wingwalls, sloping embankment Wingwalls perpendicular to abut. face

3- Spill through abutments

4- Sloping embankment, vertical wingwalls and abutments

Wingwall angle less than $90^{\circ}$.

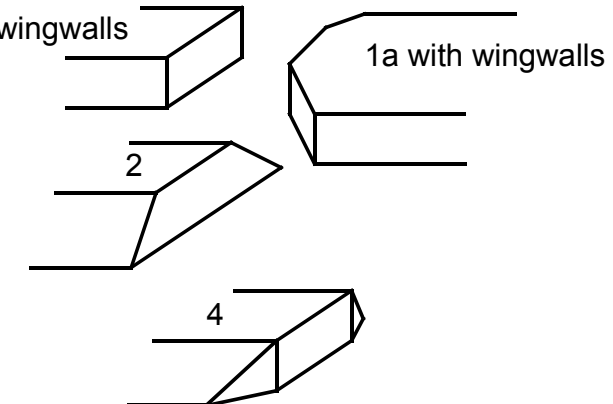

19. Bridge Deck Comments (surface cover variations, measured bridge and span lengths, bridge type variations, approach overflow width, etc.)

4. There are industry buildings and parking lots on all flood plains with some lawn on the left flood plain US and DS with forest cover beyond the buildings.

7. Values are from the VT AOT files. Measured bridge width is 41.5 feet between the outside of the curbs, bridge length is $121 \mathrm{ft}$., and the span length is $116 \mathrm{ft}$.

\section{Upstream Channel Assessment}

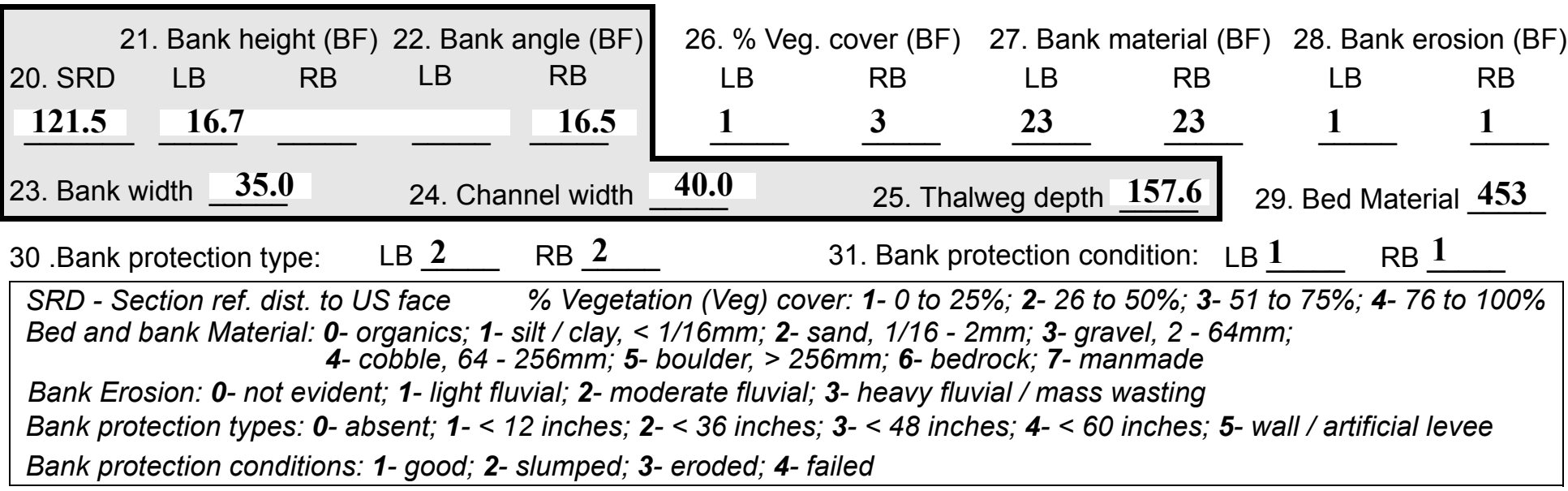

32. Comments (bank material variation, minor inflows, protection extent, etc.):

30. There is "poured concrete" or hardened factory waste along the banks that is sometimes clumpy and in other places it is continuous. There is also other debris such as bricks, metal scraps and wire along the banks. On the left bank the "poured concrete" extends from the end of the old abutment wall to $100 \mathrm{ft}$. US. On the right bank the "poured concrete" extends from $0 \mathrm{ft}$. US to $350 \mathrm{ft}$. US where it meets the bedrock outcrop. At $350 \mathrm{ft}$. US there is a concrete penstock wall built into the bedrock. There is backwater to the right of this wall and scour just DS of its nose.

26. The left bank is entirely covered with brush and no trees except a willow at $205 \mathrm{ft}$. US. 
33.Point/Side bar present? $\mathbf{N}(Y$ or $N$. if $N$ type ctrl-n pb)34. Mid-bar distance: -

35. Mid-bar width: -

36. Point bar extent: feet (US, UB) to feet (US, UB, DS) positioned $\%$ LB to $\% \mathrm{RB}$

37. Material: -

38. Point or side bar comments (Circle Point or Side; Note additional bars, material variation, status, etc.):

NO POINT BARS

39. Is a cut-bank present? $\underline{\mathbf{N}}$ (Y or if $\mathrm{N}$ type ctrl-n cb)

40. Where? - $\quad$ (LB or RB)

41. Mid-bank distance: -

42. Cut bank extent: feet (US, UB) to feet (US, UB, DS)

43. Bank damage: (1- eroded and/or creep; 2- slip failure; 3- block failure)

44. Cut bank comments (eg. additional cut banks, protection condition, etc.):

NO CUT BANKS

45. Is channel scour present? $\mathbf{Y}$ ( $Y$ or if $N$ type ctrl-n cs) 46. Mid-scour distance: $\mathbf{3 0 0}$

47. Scour dimensions: Length $\underline{\mathbf{1 5 0}}$ Width $\underline{\mathbf{3 5}}$ Depth : $\underline{\mathbf{2 . 5}}$ Position $\underline{\mathbf{4 0}} \% \mathrm{LB}$ to $\underline{\mathbf{8 0}} \% \mathrm{RB}$

48. Scour comments (eg. additional scour areas, local scouring process, etc.):

Scour extends from $225 \mathrm{ft}$. to $375 \mathrm{ft}$. US. Most of this area is scoured $1 \mathrm{ft}$. with the deepest scour close to the right bank between $260 \mathrm{ft}$. to $350 \mathrm{ft}$. US. Average thalweg depth is $1.5 \mathrm{ft}$. US.

49. Are there major confluences? $\mathbf{N}$

51. Confluence 1: Distance Confluence 2: Distance 52. Enters on Enters on 54. Confluence comments (eg. confluence name):

NO MAJOR CONFLUENCES
50. How many? -

53. Type(1-perennial; 2- ephemeral)

Type (1-perennial; 2-ephemeral) ( $L B$ or $R B)$

\section{Under Bridge Channel Assessment}

55. Channel restraint (BF)? LB 2

\begin{tabular}{|ccccc}
\hline \multicolumn{2}{|c}{56. Height (BF) } & \multicolumn{3}{c}{57 Angle (BF) } \\
LB & RB & LB & RB \\
$\mathbf{7 9 . 5}$ & & & $\mathbf{2 . 0}$ & \\
\hline
\end{tabular}
(1- natural bank; 2- abutment; 3- artificial levee)

58. Bank width (BF) 59. Channel width (Amb) -

61. Material (BF)

LB RB

$\underline{2} \quad \underline{7}$
62. Erosion (BF)

LB RB

7
60. Thalweg depth $(\mathrm{Amb}) \quad \mathbf{9 0 . 0}$

63. Bed Material -

Bed and bank Material: 0- organics; 1- silt / clay, < 1/16mm; 2- sand, 1/16 - 2mm; 3- gravel, 2 - 64mm; 4- cobble, 64 - 256mm; 5- boulder, > 256mm; 6- bedrock; 7- manmade

Bank Erosion: 0- not evident; 1- light fluvial; 2- moderate fluvial; 3- heavy fluvial / mass wasting

64. Comments (bank material variation, minor inflows, protection extent, etc.):

453

The right abutment wall is $3 \mathrm{ft}$. high at the US end and $6.5 \mathrm{ft}$. at the DS end. There is $30 \mathrm{ft}$. of stone fill with 3 slope breaks between the right edge of water and the right abutment. 
65. Debris and Ice Is there debris accumulation?

67. Debris Potential ( 1- Low; 2- Moderate; 3- High)

69. Is there evidence of ice build-up? 1 (Y or N)

70. Debris and Ice Comments:

1

Some minor scarring on a couple of trees.
$(Y$ or $N)$ 66. Where? $\mathbf{N}$

68. Capture Efficiency 1

(1- Upstream; 2- At bridge; 3- Both)

Ice Blockage Potential $\underline{Y}$
(1-Low; 2- Moderate; 3- High)

(1- Low; 2- Moderate; 3- High)

\begin{tabular}{|l|c|c|c|c|c|c|c|c|}
\hline Abutments & $\begin{array}{c}\text { 71. Attack } \\
\angle \text { (BF) }\end{array}$ & $\begin{array}{c}\text { 72. Slope } \angle \\
\text { (Qmax) }\end{array}$ & $\begin{array}{c}\text { 73. Toe } \\
\text { loc. (BF) }\end{array}$ & $\begin{array}{c}\text { 74. Scour } \\
\text { Condition }\end{array}$ & $\begin{array}{c}75 . \text { Scour } \\
\text { depth }\end{array}$ & $\begin{array}{c}\text { 76. Exposure } \\
\text { depth }\end{array}$ & 77. Material & 78. Length \\
\hline LABUT & & $\mathbf{0}$ & $\mathbf{9 0}$ & $\mathbf{2}$ & $\mathbf{0}$ & - & - & $\mathbf{9 0 . 0}$ \\
\hline RABUT & $\mathbf{1}$ & $\mathbf{0}$ & $\mathbf{9 0}$ & & & $\mathbf{2}$ & $\mathbf{0}$ & $\mathbf{1 0 9 . 0}$ \\
\hline
\end{tabular}

Pushed: $L B$ or RB

Toe Location (Loc.): 0- even, 1- set back, 2- protrudes

Scour cond.: 0- not evident; 1- evident (comment); 2- footing exposed; 3-undermined footing; 4- piling exposed; 5- settled; 6- failed

Materials: 1- Concrete; 2- Stone masonry or drywall; 3- steel or metal; 4- wood

79. Abutment comments (eg. undermined penetration, unusual scour processes, debris, etc.):

$-$

1

80. Wingwalls:

$\begin{array}{lllll} & & & & \\ \text { Exist? Material? } & \text { Scour } & \text { Scour } & \text { Exposure } & \text { Angle? Length? } \\ & \text { Condition? } & \text { depth? } & \text { depth? }\end{array}$

USLWW:

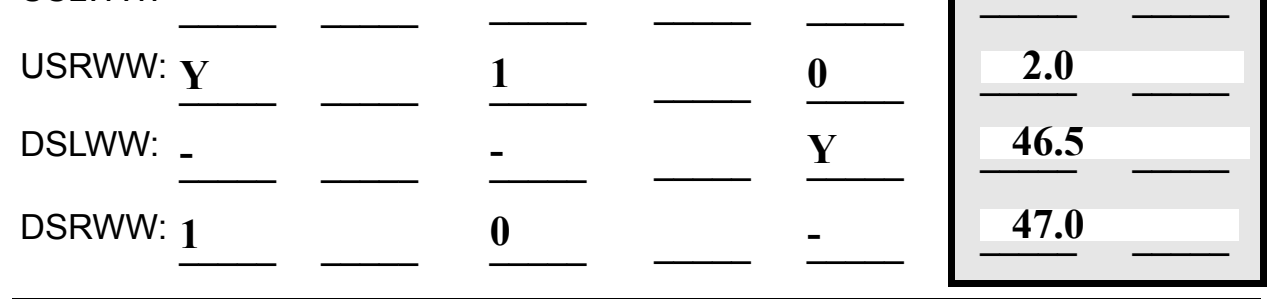

Wingwall materials: 1- Concrete; 2- Stone masonry or drywall; 3- steel or metal; 4- wood

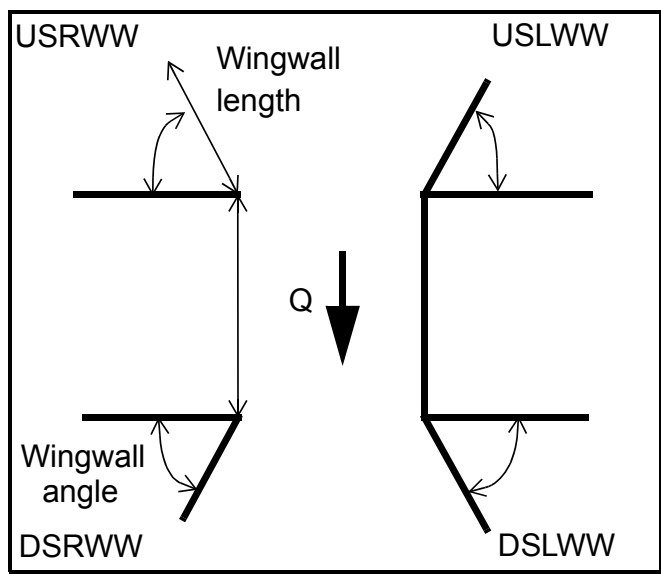

82. Bank / Bridge Protection:

\begin{tabular}{|l|l|l|l|l|l|l|c|c|}
\hline Location & USLWW & USRWW & LABUT & RABUT & LB & RB & DSLWW & DSRWW \\
\hline Type & - & $\mathbf{0}$ & $\mathbf{Y}$ & - & - & - & - & $\mathbf{1}$ \\
\hline Condition & $\mathbf{Y}$ & - & $\mathbf{1}$ & - & - & - & - & $\mathbf{1}$ \\
\hline Extent & $\mathbf{1}$ & - & $\mathbf{0}$ & $\mathbf{0}$ & $\mathbf{0}$ & $\mathbf{0}$ & $\mathbf{1}$ & - \\
\hline
\end{tabular}

Bank / Bridge protection types: 0- absent; 1- < 12 inches; 2- < 36 inches; 3- < 48 inches; 4- < 60 inches; 
83. Wingwall and protection comments (eg. undermined penetration, unusual scour processes, etc.):

-
-
-
-
-
2
1
1
1
1
1

Piers:

84. Are there piers? Th (Y or if N type ctrl-n pr)

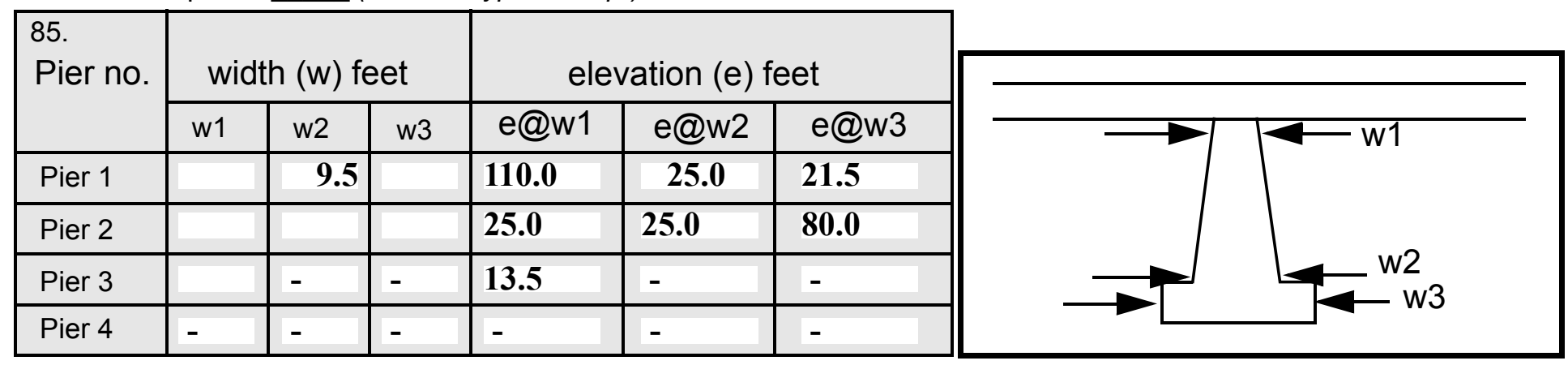

\begin{tabular}{|l|l|l|l|l|}
\hline Level 1 Pier Descr. & \multicolumn{1}{|c|}{1} & \multicolumn{1}{|c|}{2} & \multicolumn{1}{|c|}{3} & \multicolumn{1}{|c|}{4} \\
\hline 86. Location (BF) & e US & cov- & the & plan \\
\hline 87. Type & right & ered & wing & e \\
\hline 88. Material & wing & by & wall & exte \\
\hline 89. Shape & wall & an & joins & ndin \\
\hline 90. Inclined? & is set & eart & an & g 40 \\
\hline 91. Attack $\angle$ (BF) & high & hen & old & ft. \\
\hline 92. Pushed & on & bank & abut & US. \\
\hline 93. Length (feet) & - & - & - & - \\
\hline 94. \# of piles & the & . On & ment & Ther \\
\hline 95. Cross-members & bank & the & wall & e is \\
\hline 96. Scour Condition & and & US & on & also \\
\hline 97. Scour depth & is & left & the & a \\
\hline 98. Exposure depth & half & side, & same & wing \\
\hline
\end{tabular}

LFP, LTB, LB, MCL, MCM, MCR, RB, RTB, RFP

1- Solid pier, 2- column, 3- bent

1-Wood; 2-concrete; 3- metal; 4- stone

1- Round; 2- Square; 3- Pointed

Y-yes; $N$ - no

$L B$ or $R B$

0- none; 1- laterals; 2- diagonals; 3- both

0- not evident; 1- evident (comment);

2- footing exposed; 3- piling exposed;

4- undermined footing; 5- settled; 6- failed 
99. Pier comments (eg. undermined penetration, protection and protection extent, unusual scour processes, etc.):

wall in good shape on the US end of this older abutment. The footing is exposed $2 \mathrm{ft}$. along the length of the old abutment, but it is not undermined. The wingwall is at a 60 degree angle to the abutment. A 6 in. corrugated metal outfall pipe is laying along the base of the DS left wingwall. There is a trickle of discharge during the assessment. The right abutment protection refers to the flow through type stone fill described in 64. On the US left wingwall there are a couple of large boulders acting as protection.

$\mathbf{N}$

100.

\section{E. Downstream Channel Assessment}

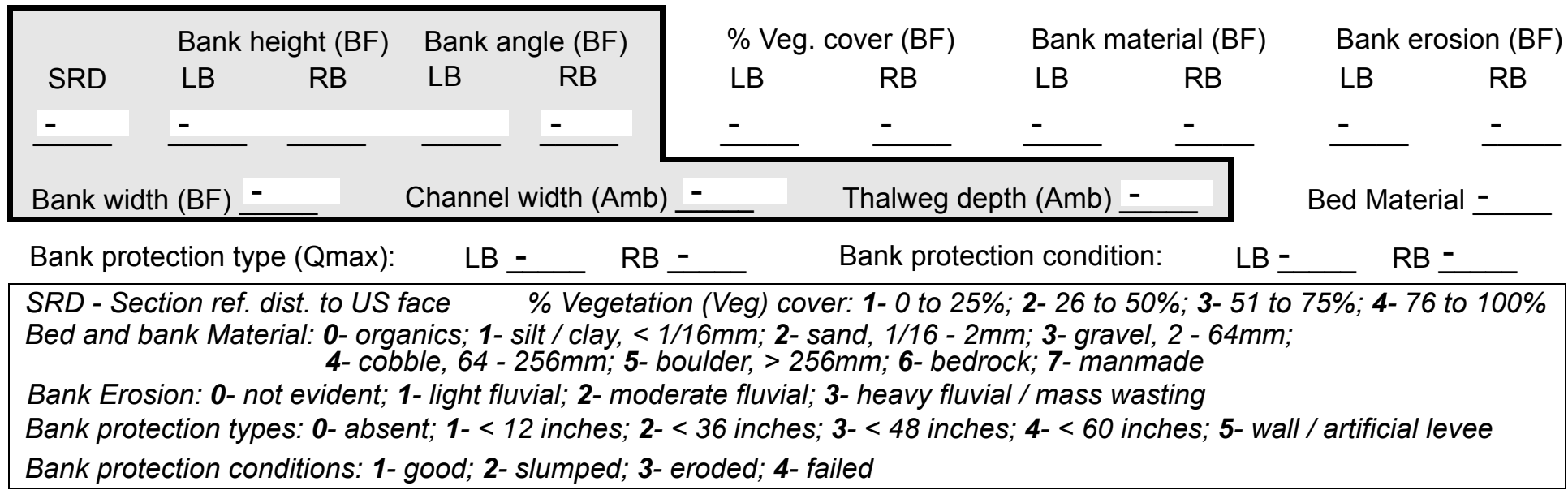

Comments (eg. bank material variation, minor inflows, protection extent, etc.):

$-$

-

-

-

$-$

-

-

-

-

-

101. Is a drop structure present? _ ( $Y$ or $N$, if $N$ type ctrl-n ds) 102. Distance: ___ feet 103. Drop: __ feet 104. Structure material: ___ (1- steel sheet pile; 2- wood pile; 3- concrete; 4- other) 105. Drop structure comments (eg. downstream scour depth):

-

$-$ 
106. Point/Side bar present? (Y or $N$. if $N$ type ctrl-n pb)Mid-bar distance:

Mid-bar width: -

Point bar extent: feet -

(US, UB, DS) to feet (US, UB, DS) positioned $\%$ LB to $\% \mathrm{RB}$ Material:

Point or side bar comments (Circle Point or Side; note additional bars, material variation, status, etc.):

S a cut-bank present? $\mathbf{N}$ (Y or if $N$ type ctrl-n cb) Where? $\underline{\mathbf{O}}$ (LB or RB) Mid-bank distance: PIE Cut bank extent: $\underline{\mathbf{R S}}$ feet ___ (US, UB, DS) to feet (US, UB, DS)

Bank damage: (1- eroded and/or creep; 2- slip failure; 3- block failure)

Cut bank comments (eg. additional cut banks, protection condition, etc.):

Is channel scour present? Scour dimensions: Length 1 Width 32 ( $Y$ or if $N$ type ctrl-n cs) Depth: 345 Mid-scour distance: 1 Scour comments (eg. additional scour areas, local scouring process, etc.): 453

2

5

2

Are there major confluences? 1 ( $Y$ or if $N$ type ctrl-n $m c)$ Confluence 1: Distance left Enters on ban (LB or RB) Confluence 2: Distance vegeEnters on tatio (LB or RB) Positioned 1 \%LB to 1 $\% \mathrm{RB}$ Confluence comments (eg. confluence name):

cover is shrubs. The right bank vegetation cover is a few trees and shrubs from the bridge to $100 \mathrm{ft}$. DS. Then the cover increases to between $76 \%$ and $100 \%$. On the right bank there is a $9 \mathrm{ft}$. high concrete wall extending

\section{F. Geomorphic Channel Assessment}

107. Stage of reach evolution fro
1- Constructed

2- Stable

3- Aggraded

4- Degraded

5- Laterally unstable

6- Vertically and laterally unstable 
108. Evolution comments (Channel evolution not considering bridge effects; See HEC-20, Figure 1 for geomorphic descriptors):

$m$ the end of the wingwall to $89 \mathrm{ft}$. DS. The left bank protection extends from the bridge to $400 \mathrm{ft}$. DS at the bedrock outcrop. It consists of slabs of concrete and other conglomerates dumped mostly at the bottom of the bank. The bedrock on the left bank $400 \mathrm{ft}$. from the bridge forces a bend towards the right. There is scour at this bend. A sand bar is on the right bank from $40 \mathrm{ft}$. to $85 \mathrm{ft}$. DS. It is $22 \mathrm{ft}$. wide and extends out from the base of the wall. It is cut by discharge from a $2.5 \mathrm{ft}$. pipe outfall. 


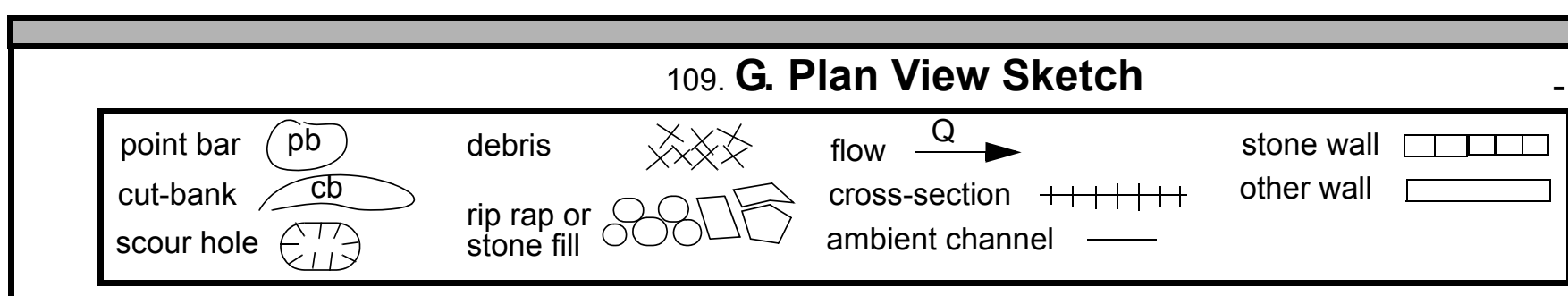


APPENDIX F:

SCOUR COMPUTATIONS 


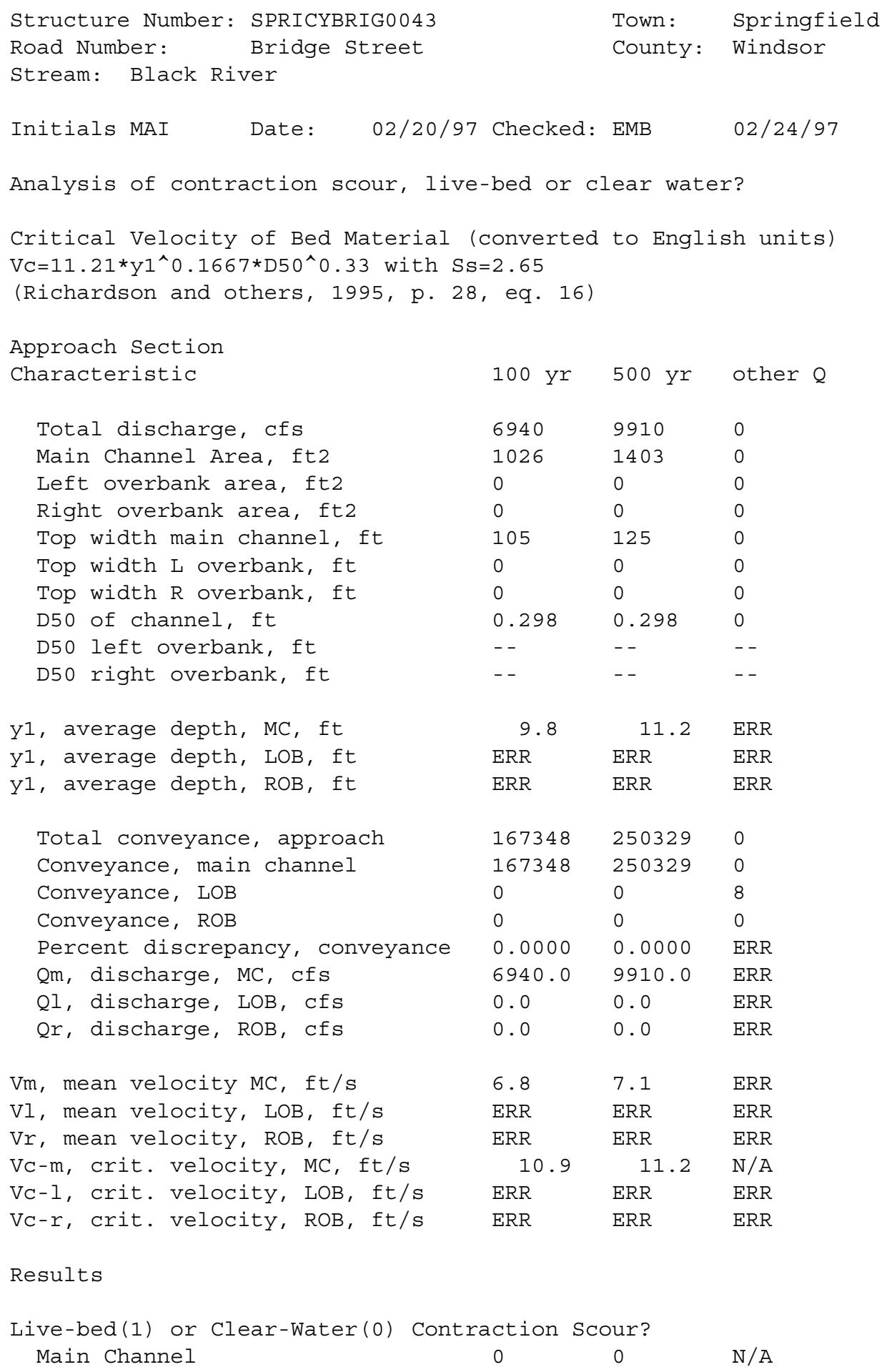




$\begin{array}{llll}\text { ARMORING } & & & \\ \text { D90 } & 0.808 & 0.808 & 0 \\ \text { D95 } & 1.092 & 1.092 & 0 \\ \text { Critical grain size,DC, ft } & 0.1381 & 0.2501 & \text { ERR } \\ \text { Decimal-percent coarser than DC } & 0.879 & 0.628 & 0 \\ \text { Depth to armoring,ft } & 0.06 & 0.44 & \text { ERR }\end{array}$

Clear water Contraction Scour in MAIN CHANNEL

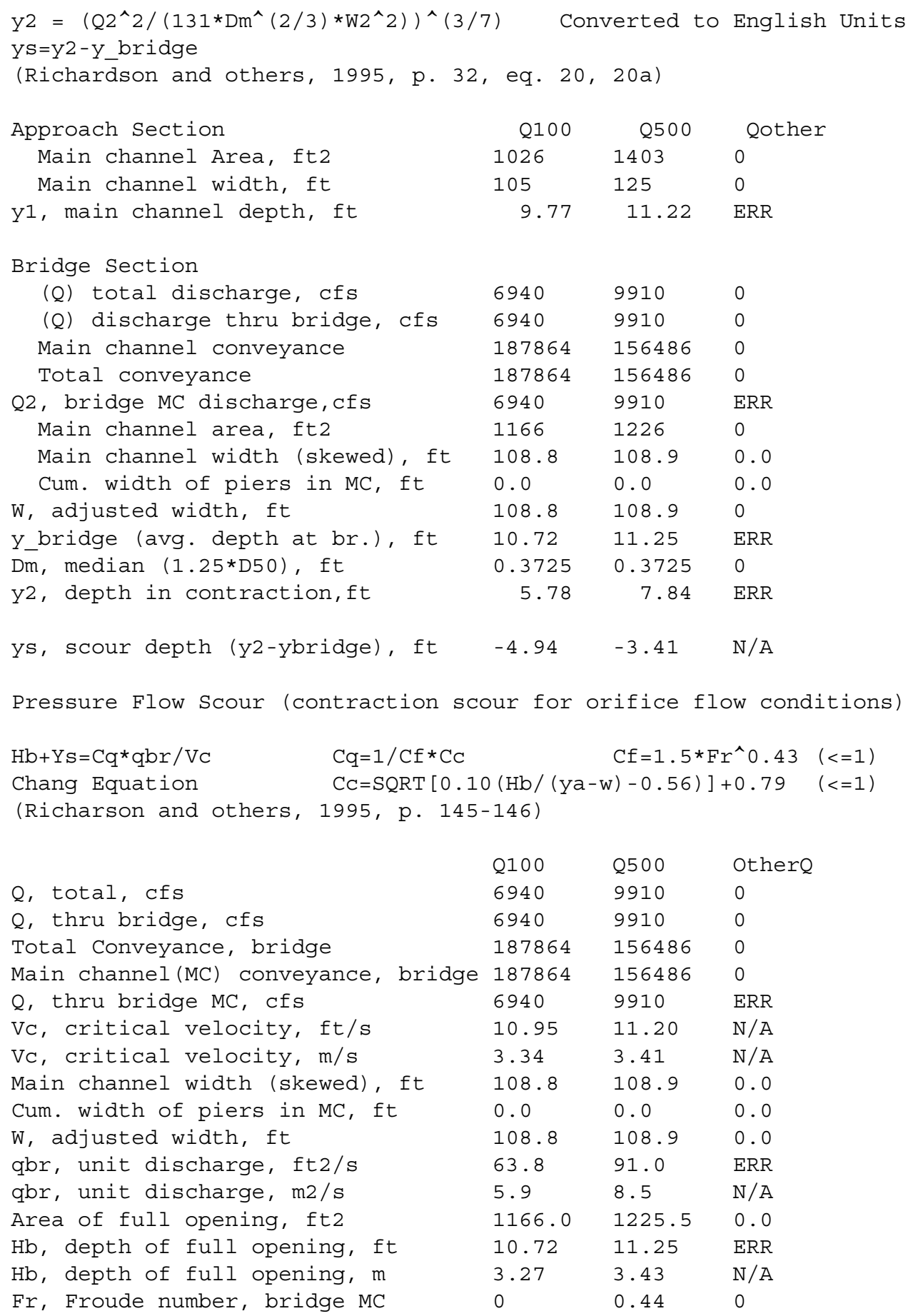




$\begin{array}{llll}\text { Cf, Fr correction factor }(<=1.0) & 0.00 & 1.00 & 0.00 \\ \text { Elevation of Low Steel, ft } & 0 & 493.37 & 0 \\ \text { Elevation of Bed, ft } & -10.72 & 482.12 & \mathrm{~N} / \mathrm{A} \\ \text { Elevation of Approach, ft } & 0 & 496.38 & 0 \\ \text { Friction loss, approach, ft } & 0 & 0.27 & 0 \\ \text { Elevation of WS immediately US, ft } & 0.00 & 496.11 & 0.00 \\ \text { ya, depth immediately US, ft } & 10.72 & 13.99 & \mathrm{~N} / \mathrm{A} \\ \text { ya, depth immediately US, m } & 3.27 & 4.26 & \mathrm{~N} / \mathrm{A} \\ \text { Mean elevation of deck, ft } & 0 & 501.02 & 0 \\ \text { w, depth of overflow, ft (>=0) } & 0.00 & 0.00 & 0.00 \\ \text { CC, vert contrac correction }(<=1.0) & 1.00 & 0.95 & \mathrm{ERR} \\ \text { Ys, depth of scour, ft } & \mathrm{N} / \mathrm{A} & -2.67 & \mathrm{~N} / \mathrm{A}\end{array}$

Abutment Scour

Froehlich's Abutment Scour

$\mathrm{Ys} / \mathrm{Y} 1=2.27 * \mathrm{~K} 1 * \mathrm{~K} 2 *\left(\mathrm{a}^{\prime} / \mathrm{Y} 1\right) \wedge 0.43 * \mathrm{Fr} 1 \wedge 0.61+1$

(Richardson and others, 1995, p. 48, eq. 28)

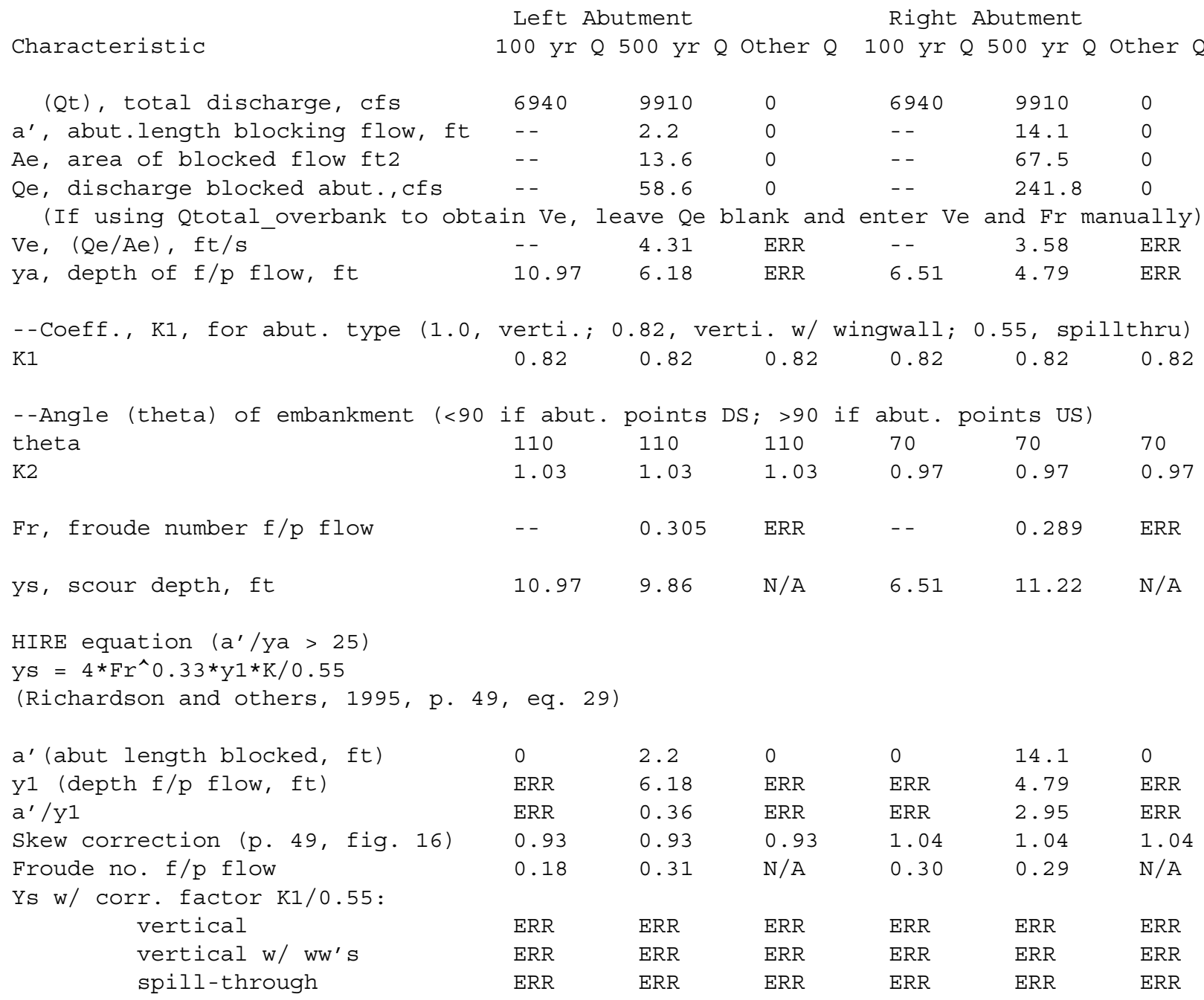




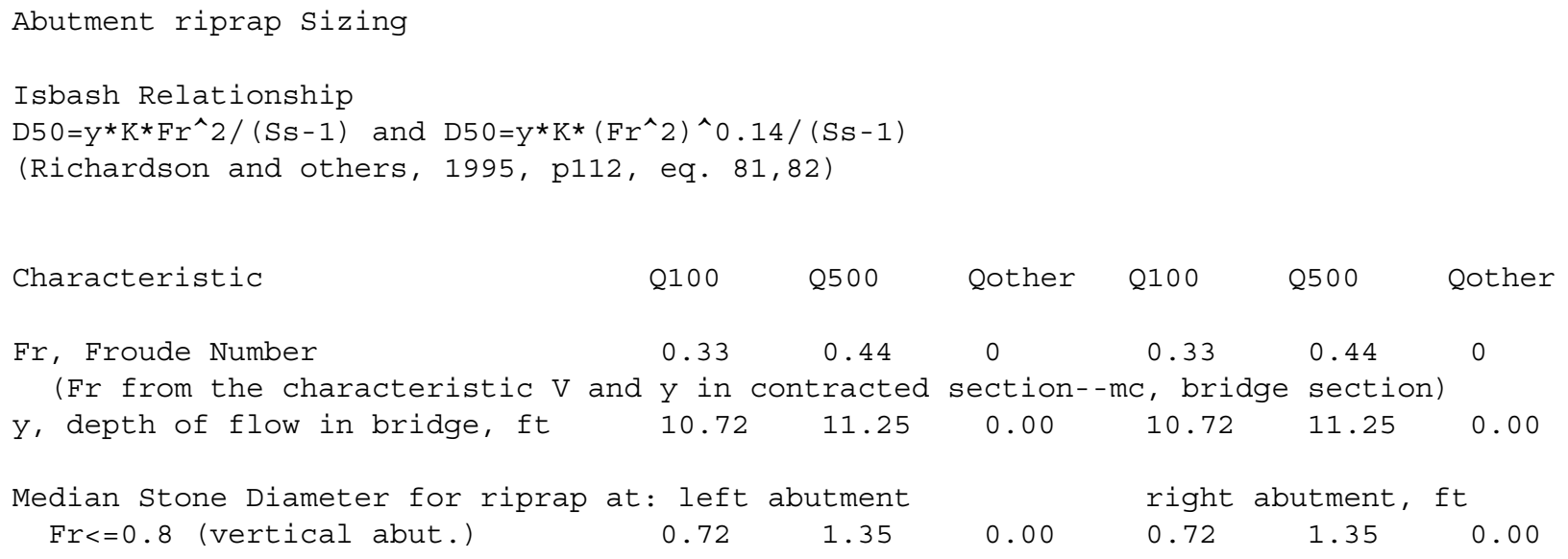

